University of New Hampshire

University of New Hampshire Scholars' Repository

Civil and Environmental Engineering

Scholarship

Civil and Environmental Engineering

$10-15-2017$

\title{
Organic compounds in hydraulic fracturing fluids and wastewaters: A review
}

Jenna L. Luek

University of New Hampshire, Durham, Jenna.Luek@unh.edu

Michael Gonsior

University of Maryland

Follow this and additional works at: https://scholars.unh.edu/civeng_facpub

Comments

This is an Accepted Manuscript of an article published by Elsevier in Water Research in 2017, available online:

https://dx.doi.org/10.1016/j.watres.2017.07.012. This manuscript version is made available under the CC-BY-NC-ND 4.0 license http://creativecommons.org/licenses/by-nc-nd/4.0/

\section{Recommended Citation}

Luek, J.L., Gonsior, M. 2017. A Review of Organic Compounds in Hydraulic Fracturing Fluids and Wastewaters. Water Research 123, 536-548. DOI:10.1016/j.watres.2017.07.012

This Article is brought to you for free and open access by the Civil and Environmental Engineering at University of New Hampshire Scholars' Repository. It has been accepted for inclusion in Civil and Environmental Engineering Scholarship by an authorized administrator of University of New Hampshire Scholars' Repository. For more information, please contact Scholarly.Communication@unh.edu. 
1 Organic Compounds in Hydraulic Fracturing Fluids and Wastewaters: A Review

2

3 Jenna L. Luek ${ }^{1 *}$ and Michael Gonsior ${ }^{1}$

4 1. University of Maryland Center for Environmental Science, Chesapeake Biological

5 Laboratory, Solomons, Maryland 20688, USA

6 Water Research, accepted manuscript. Published article can be found at:

7 https://doi.org/10.1016/j.watres.2017.07.012

8 (C) 2017. This manuscript version is made available under the CC-BY-NC-ND 4.0 license:

9 http://creativecommons.org/licenses/by-nc-nd/4.0/

10

11 *Corresponding Author: Jenna Luek, Telephone: +14126054898,Email: jluek88@gmail.com

12

13

14

15 Key words: high volume hydraulic fracturing, fracking, flowback fluid, produced water 


\section{Graphical Abstract}

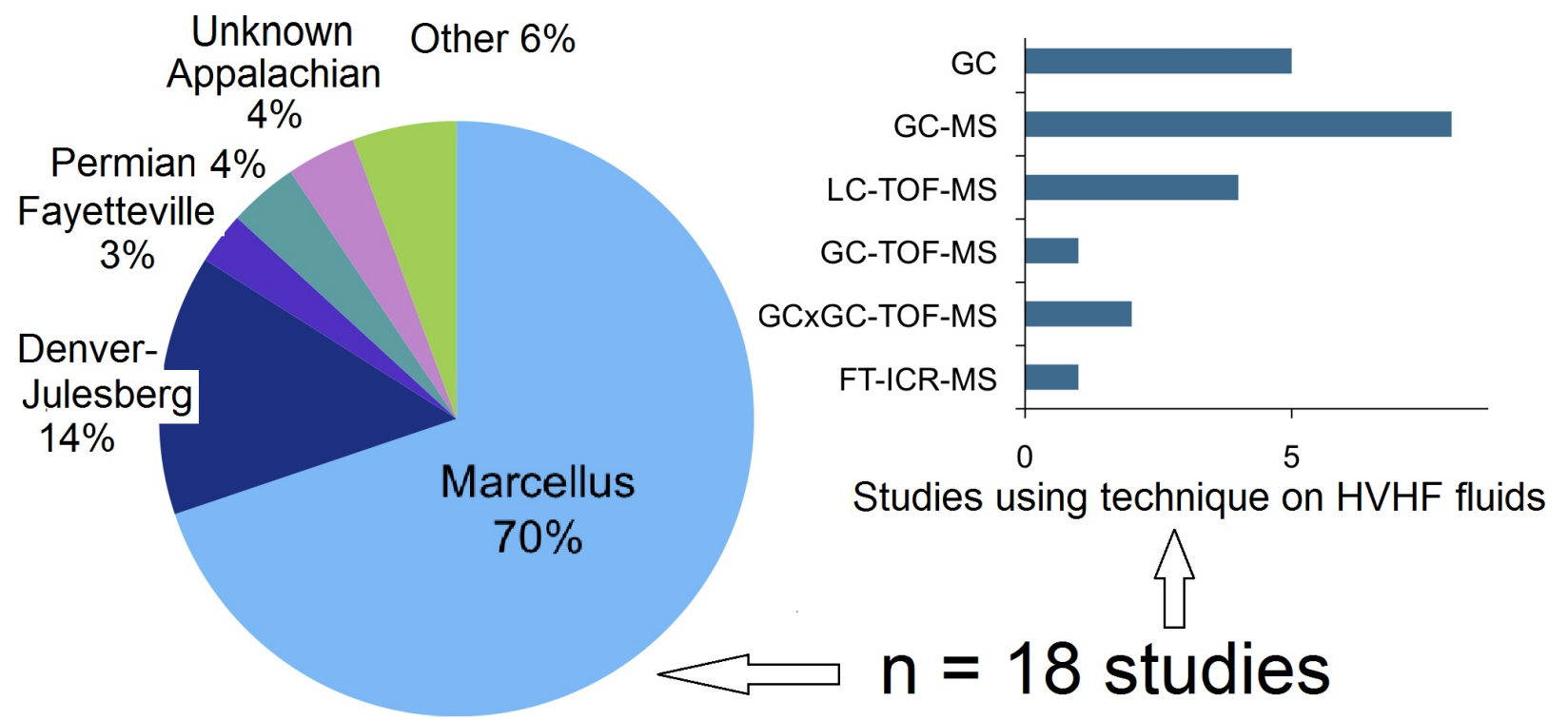

Organic chemical analyses

\section{Highlights}

20 - GC and GC-MS are key analytical techniques used for organic chemical analysis

21 - BTEX, acetate, and acetone are the most frequently analyzed organic compounds

22 - Diverse halogenated organic compounds have been detected in flowback fluids

23 - Organic additives have been used to infer environmental contamination

24 - Development of new standards and standard methods for quantification are needed 


\section{Abstract}

High volume hydraulic fracturing (HVHF) of shale to stimulate the release of natural gas

28 produces a large quantity of wastewater in the form of flowback fluids and produced water.

29 These wastewaters are highly variable in their composition and contain a mixture of fracturing

30 fluid additives, geogenic inorganic and organic substances, and transformation products. The

31 qualitative and quantitative analyses of organic compounds identified in HVHF fluids, flowback

32 fluids, and produced waters are reviewed here to communicate knowledge gaps that exist in the

33 composition of HVHF wastewaters. In general, analyses of organic compounds have focused on

34 those amenable to gas chromatography, focusing on volatile and semi-volatile compounds oil

35 and gas compounds. Studies of more polar and non-volatile organic compounds have been

36 limited by a lack of knowledge of what compounds may be present as well as quantitative

37 methods and standards available for analyzing these complex mixtures. Liquid chromatography

38 paired with high-resolution mass spectrometry has been used to investigate a number of additives

39 and will be a key tool to further research on transformation products that are increasingly

40 solubilized through physical, chemical, and biological processes in situ and during

41 environmental contamination events. Diverse treatments have been tested and applied to HVHF

42 wastewaters but limited information has been published on the quantitative removal of individual

43 organic compounds. This review focuses on recently published information on organic

44 compounds identified in flowback fluids and produced waters from HVHF. 


\section{Introduction}

Shale gas extraction via high volume hydraulic fracturing (HVHF) has resulted in the use of 116 billion liters of fluids annually from 2012-2014 and yielded similar volumes of flowback and produced waters (Kondash and Vengosh, 2015). These fluids contain a complex mixture of inorganic and organic compounds used as additives (Elsner and Hoelzer, 2016; Stringfellow et al., 2014) as well as compounds extracted from the shale itself including salts, metals, radionuclides, oil and gas compounds, and natural organic matter (NOM) (Abualfaraj et al., 2014; Chapman et al., 2012; Engle and Rowan, 2014). Understanding these complex fluid mixtures is essential for understanding efficacy of additives, fluid treatment options for reuse in future HVHF jobs or discharge, and threats to the natural environment and human exposure. The identification and quantification of individual organic compounds among the complex mixture of additives, oil and gas compounds, NOM, and transformation products requires diverse sample preparation and analytical techniques (Ferrer and Thurman, 2015a). Mass spectral techniques provide data of variable confidence ranging from having only the exact masses of interest to having confirmed structures by reference standards (Schymanski et al., 2014). Gas chromatography paired with mass spectrometry has been traditionally used to identify hydrophobic oil and gas hydrocarbons found in produced waters (Ferrer and Thurman, 2015a; Maguire-Boyle and Barron, 2014; Orem et al., 2014; Strong et al., 2013), and can be used to quantify many of the compounds in HVHF fluids and wastewaters of known toxicity (Elliott et al., 2017). Liquid chromatography paired with mass spectrometry has been shown to be useful in identifying many of the more hydrophilic organic compounds used in HVHF additives such as ethoxylated surfactants (Ferrer and Thurman, 2015a, 2015b; Getzinger et al., 2015; Hoelzer et al., 2016), but further method development requires overcoming analytical barriers such as the 
68 complex high salinity matrix. Analytical methods for describing unknown shale extracts and

69 transformation products will require higher resolution techniques such as two dimensional gas

70 chromatography with time of flight mass spectrometry (GC $\times$ GC-TOF-MS) (Hoelzer et al.,

71 2016), liquid chromatography with time of flight mass spectrometry (LC-TOF-MS) (Ferrer and

72 Thurman, 2015b; Thurman et al., 2014), and Fourier transform ion cyclotron resonance mass

73 spectrometry (FT-ICR-MS), each requiring laborious data analysis and interpretation. Time of

74 flight mass spectrometry can provide sufficiently high resolution that exact masses can be

75 combined with GC or LC to determine unknown molecular formulas and structures with

76 relatively high confidence in the absence of standards, especially when combined with

77 fragmentation spectra (Ferrer and Thurman, 2015b; Marshall and Hendrickson, 2008; Thurman

78 et al., 2014). Ultrahigh resolution FT-ICR-MS allows for direct determination of the assigned

79 molecular formula based on the exact mass alone but provides no direct details on molecular

80 structure (Marshall and Hendrickson, 2008) unless paired with MS-MS techniques. However,

81 large numbers of possible isomers at higher masses make this approach challenging, but this

82 challenge might be partially overcome by using LC.

83 Organic compounds observed in these fluids have been characterized by their mobility,

84 persistence, toxicity, and frequency of use to understand the level of concern for human exposure

85 via groundwater (Rogers et al., 2015). However, the combination of multiple organic

86 compounds, inorganic compounds, and multiple phases complicates modeling the behavior of

87 these organic compounds in the natural environment. Experimental and field studies are needed

88 to address questions of mobility, persistence, and toxicity of HVHF fluid additives, geogenic

89 organic compounds, and potential transformation products. 
A number of studies have worked to identify analytical methods and quantify organic

91 compounds in HVHF fluids, flowback fluids, and produced waters, and describe how these

92 compounds are transformed within diverse environments. However, these studies have yet to be

93 synthesized to provide a holistic perspective on the processes controlling organic compounds

94 within these fluids. This review aims to synthesize existing literature on organic compounds

95 quantitatively and qualitatively identified in HVHF fluids, flowback fluids and produced waters.

96 Additionally, this review focuses on the distribution of HVHF associated organic compounds

97 during environmental contamination and their use as tracers of contamination, the removal

98 efficiencies of specific organic compounds during wastewater treatment, and makes

99 recommendations for future research.

100

101 2. Hydraulic Fracturing Fluid Additives

102 The majority of organic additives included in HVHF fluid have been described by class

103 and their frequency of use (Elsner and Hoelzer, 2016; Rogers et al., 2015). Additionally, lists of

104 additives are publicly available through the website FracFocus (fracfocus.org) and are

105 summarized in the EPA hydraulic fracturing study report (U.S. EPA, 2016). Organic compounds

106 are used at every stage in the HVHF process: 1) mixing of the base fluid including solvent and

107 surfactants, 2) as cross linkers and breakers, 3) clay stabilizers, 4) corrosion, scale, and 5)

108 biofouling inhibitors (Elsner and Hoelzer, 2016; Stringfellow et al., 2014). Alcohols are the

109 dominant organic class used in a number of functions including as solvents (methanol,

110 isopropanol, ethanol), surfactants (ethylene glycol, ethoxylated alcohols and phenols) and

111 corrosion inhibitors (propargyl alcohol) (Elsner and Hoelzer, 2016). Polymers are also used in a

112 large number of processes including as gelling agents, friction reducers, proppant coatings, 
113 corrosion and scale inhibitors (Elsner and Hoelzer, 2016). Many synthetic polymers and

114 biopolymers are readily biodegraded, although their monomers may be of environmental concern

115 (Elsner and Hoelzer, 2016; Stringfellow et al., 2014). Hydrocarbons, as light and heavy

116 petroleum distillate mixtures and individual compounds (naphthalene, tetradecane, limonene),

117 are an additional dominant class of additives, used primarily as solvents (Elsner and Hoelzer, 118 2016).

119 Of the remaining additives, some are specifically added to be reactive. For example, 120 strong oxidants are used as biocides (infrequently) (Kahrilas et al., 2015) and as breakers (77\%

121 of surveyed well disclosure lists) (Elsner and Hoelzer, 2016). Glutaraldehyde and

122 dibromonitrilopropionamide are the dominant biocides used (27\% and $24 \%$, respectively) and

123 behave by reacting with specific function groups (thiol, amino, sulfhydryl) and destroying 124 protein function (Kahrilas et al., 2015; Maillard, 2002). Breakers are used to "break" polymers 125 and reduce surface tension of the fluid, allowing flowback fluids to return to the surface. These 126 breakers and biocides may react not only with their targets, but also on the other organic

127 compounds present as additives or from geogenic sources and result in unknown transformation 128 products (Hoelzer et al., 2016; Luek et al., 2017; Maguire-Boyle and Barron, 2014).

\section{3. Flowback and Produced Waters}

130 Specific organic compounds have been analyzed both qualitatively and quantitatively in 131 more than 238 flowback and produced water samples from hydraulically fractured shale gas

132 wells in published literature (Table 1, Fig. 1). These analyses have focused on both oil and gas 133 related compounds (e.g., hydrocarbons, benzene, toluene, ethylbenzene and xylene [BTEX]), 134 small organic acids related to microbial degradation, and other additives. Confidence in 135 identification of organic compounds is variable, with some compounds identified quantitatively 
136 using standards while others rely on spectral libraries or match of exact mass due to a lack of

137 standards and standardized methods (Schymanski et al., 2014). The use of quantitative

138 techniques $\left({ }^{\mathrm{q}}\right)$, standards $\left({ }^{\mathrm{s}}\right)$, or spectral libraries $\left({ }^{\mathrm{l}}\right)$ is indicated in Table 1 by publication and

139 technique.

140 Seventy percent of the samples analyzed for organic compounds have been collected

141 from the Marcellus shale basin, which makes up $37 \%$ of unconventional natural gas production

142 but less than $0.01 \%$ of oil production (Drilling Productivity Report, 2017). Gas chromatography

143 has been used extensively in these studies for volatile and semi-volatile organic compound

144 (VOC, SVOC) analyses (Table 1). Ion chromatography (IC) has also been used to analyze small

145 organic acids (Akob et al., 2015; Lester et al., 2013). High resolution LC-TOF-MS has been used

146 to investigate specific additives, focusing mostly on samples from Weld County, Colorado in the

147 Denver-Julesberg basin (Ferrer and Thurman, 2015b; Rosenblum et al., 2016; Thurman et al.,

148 2014). Organic analyses have also been performed on samples collected from the Barnett shale

149 (Maguire-Boyle and Barron, 2014; Thurman et al., 2014), the Wolfcamp and Cline shales in the

150 Permian basin (Khan et al., 2016), New Albany shale (Orem et al., 2014), an unknown formation

151 in Texas (Thacker et al., 2015), a single sample from each of the Eagle Ford, Fayetteville,

152 Burket, and unspecified formations in Pennsylvania, Nevada, and Louisiana. 

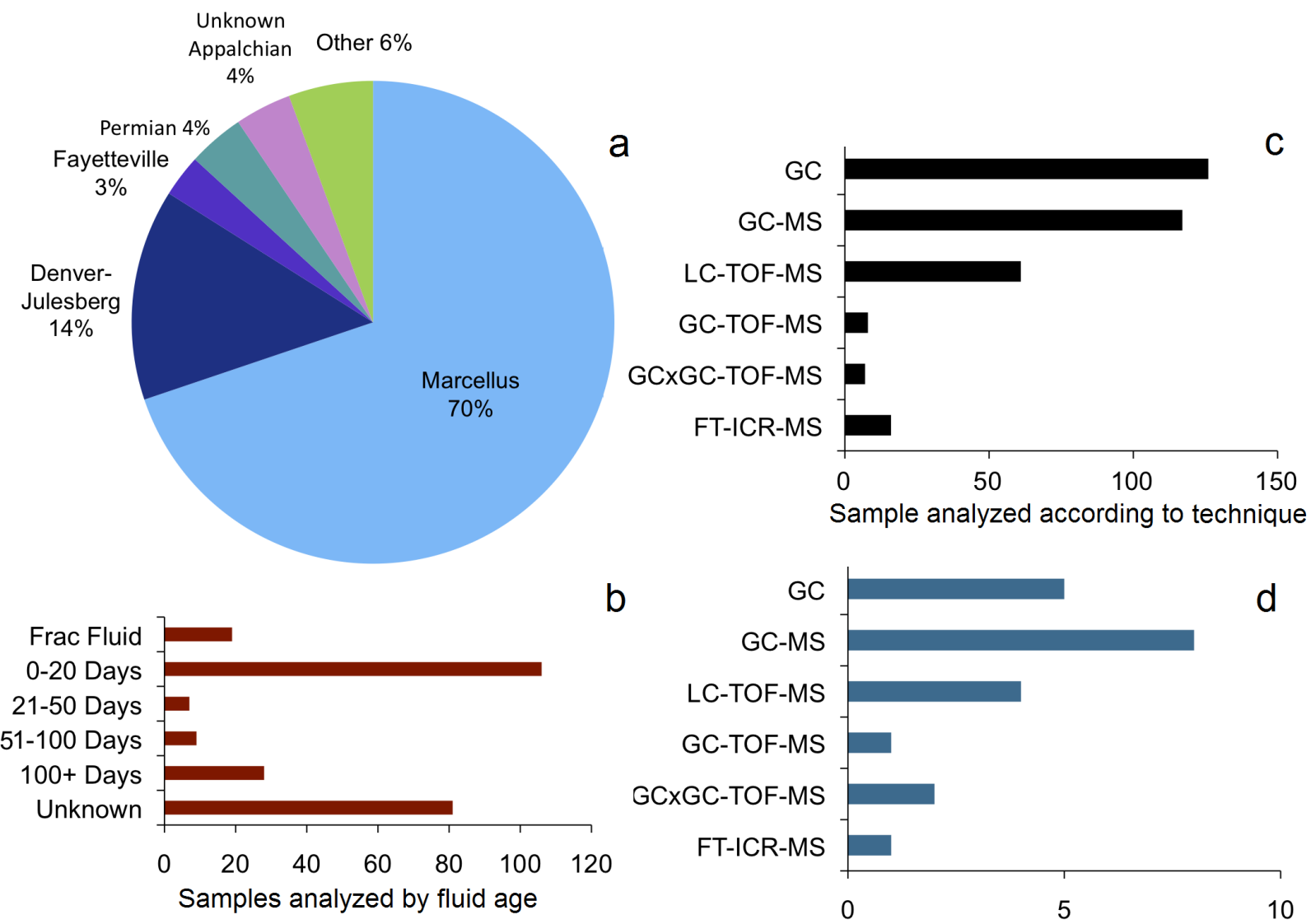

b

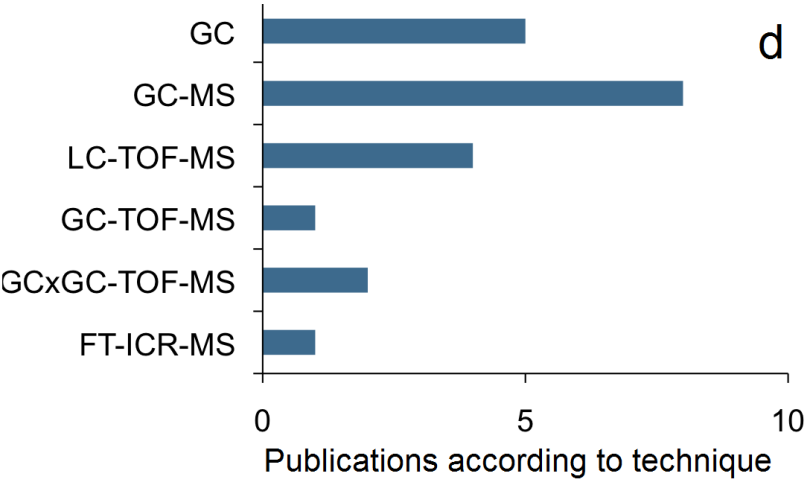

155 Figure 1. Summary of flowback and produced water samples analyzed to date for organic 156 compounds in 18 studies given in Table 1. a) by basin b) fluid age c) analytical technique and d) 157 number of publications by analytical technique.

Table 1. Published reports and peer-reviewed literature analyzing organic compounds in shale gas flowback and produced waters. ${ }^{\mathrm{q}}$ quantitative; ${ }^{\mathrm{s}}$ compared to standards; ${ }^{1}$ compared to spectral 162 library $^{\wedge}$ sample origins not precisely specified and up to 5 may overlap with samples reported by

163 Lester et al., 2015; Rosenblum et al., 2016. *MBA, methyl blue active substances (for anionic

164 surfactants).

\begin{tabular}{|l|l|l|l|l|}
\hline $\begin{array}{l}\text { Basin/Shale } \\
\text { Gas } \\
\text { Formation } \\
\text { (state) }\end{array}$ & $\begin{array}{l}\text { Fluid Type (time of } \\
\text { sampling) }\end{array}$ & $\begin{array}{l}\text { Analytical Method for Organic } \\
\text { Compound Identification } \\
\text { (targeted classes) }\end{array}$ & $\begin{array}{l}\text { Number } \\
\text { of } \\
\text { Samples }\end{array}$ & Source \\
\hline $\begin{array}{l}\text { Marcellus (PA), } \\
\text { Burket (PA) }\end{array}$ & $\begin{array}{l}\text { Produced (5 months - } \\
38 \text { months) }\end{array}$ & $\begin{array}{l}\text { GC-MS (VOCs } \\
\text { IC (organic acids) }\end{array}$ & 13 & (Akob et al., 2015) \\
\hline Marcellus (PA) & $\begin{array}{l}\text { Flowback and } \\
\text { Produced }\end{array}$ & $\begin{array}{l}\text { GC (alkenes, alkanes, acetate), } \\
\text { LC-TOF-MS (ethxoylated } \\
\text { surfactants) }\end{array}$ & 31 & (Cluff et al., 2014) \\
\hline $\begin{array}{l}\text { Denver- } \\
\text { Julesberg (CO) }\end{array}$ & $\begin{array}{l}\text { Flowback and } \\
\text { Produced }\end{array}$ & $\begin{array}{l}\text { LC-TOF-MS (gels, surfactants, } \\
\text { biocides }^{\mathrm{s}} \text { ) }\end{array}$ & $22^{\wedge}$ & $\begin{array}{l}\text { (Ferrer and } \\
\text { Thurman, 2015b) }\end{array}$ \\
\hline
\end{tabular}




\begin{tabular}{|c|c|c|c|c|}
\hline $\begin{array}{l}\text { Marcellus (PA, } \\
\text { WV) }\end{array}$ & $\begin{array}{l}\text { Flowback (Day 1, 5, } \\
\text { 14) Produced (Day 90) }\end{array}$ & $\begin{array}{l}\text { GC-MS (VOCs, SVOCs, } \\
\text { pesticides }^{\mathrm{q}, \mathrm{s}} \text { ) GC-ECD }\left(\mathrm{PCBs}^{\mathrm{q}, \mathrm{s}}\right) \\
\text { GC-FID (ethylene glycol }{ }^{\mathrm{q}, \mathrm{s}} \text { ) }\end{array}$ & 78 & (Hayes, 2009) \\
\hline $\begin{array}{l}\text { Fayetteville } \\
\text { (AR) }\end{array}$ & $\begin{array}{l}\text { Flowback (Week 0-3) } \\
\text { Produced (Week 50) }\end{array}$ & $\begin{array}{l}\text { GC-FID }\left(\text { VOCs }^{\mathrm{q}, \mathrm{s}}\right), \text { GC-MS } \\
\text { (SVOCs), GCxGC-FID and } \\
\text { GCxGC-TOF-MS (SVOCs) }\end{array}$ & 6 & $\begin{array}{l}\text { (Hoelzer et al., } \\
\text { 2016) }\end{array}$ \\
\hline $\begin{array}{l}\text { Permian- } \\
\text { Wolfcamp, } \\
\text { Cline (TX) }\end{array}$ & $\begin{array}{l}\text { Produced (Day 130- } \\
441 \text { ) }\end{array}$ & $\begin{array}{l}\text { GCxGC-TOF-MS (VOCs }{ }^{\mathrm{q}, \mathrm{s}, \mathrm{I}}, \\
\left.\text { SVOCs }^{\mathrm{q}, \mathrm{s}, \mathrm{l}}\right)\end{array}$ & 8 & (Khan et al., 2016) \\
\hline $\begin{array}{l}\text { Marcellus } \\
\text { (WV), Denver- } \\
\text { Julesberg (CO), } \\
\text { Utica (OH), } \\
\text { ND, PA, WV }\end{array}$ & $\begin{array}{l}\text { Flowback, Produced, } \\
\text { Compression liquids }\end{array}$ & $\begin{array}{l}\text { FT-ICR-MS (dissolved ionizable } \\
\text { (ESI-) organics) }\end{array}$ & 16 & (Luek et al., 2017) \\
\hline $\begin{array}{l}\text { Denver- } \\
\text { Julesberg (CO) }\end{array}$ & $\begin{array}{l}\text { Flowback composite } \\
\text { (unknown timing) }\end{array}$ & $\begin{array}{l}\text { IC }\left(\text { acetic acid }^{\mathrm{q}}\right), \text { GC-MS }(\mathrm{VOC}, \\
\left.\text { SVOC }^{\mathrm{q}, \mathrm{s}}\right) \text { LC-TOF-MS (trace } \\
\text { organic chemicals) }\end{array}$ & 1 & (Lester et al., 2015) \\
\hline Marcellus (PA) & Flowback & HPLC (organic acids ${ }^{\mathrm{q}}$ ) & 3 & $\begin{array}{l}\text { (Murali Mohan et } \\
\text { al., 2013b) }\end{array}$ \\
\hline $\begin{array}{l}\text { Marcellus (PA), } \\
\text { Eagle Ford } \\
\text { (TX), Barnett } \\
(\mathrm{NM})\end{array}$ & Produced (unknown) & $\begin{array}{l}\text { GC-MS (aliphatic, aromatic, resin, } \\
\text { asphaltenes, halogenated') }\end{array}$ & 3 & $\begin{array}{l}\text { (Maguire-Boyle and } \\
\text { Barron, 2014) }\end{array}$ \\
\hline $\begin{array}{l}\text { Marcellus (PA) } \\
\text { New Albany } \\
\text { (IN, KY) }\end{array}$ & $\begin{array}{l}\text { Flowback and } \\
\text { Produced (time series) }\end{array}$ & $\begin{array}{l}\text { GC-MS (PAHs, , aromatic amines, } \\
\text { phenols, heterocyclic and other } \\
\text { aromatic \& aliphatic compounds, } \\
\left.\text { phthalates, fatty acids }{ }^{\mathrm{q}, \mathrm{s}, \mathrm{l}}\right) \text {, HPLC } \\
\left(\text { volatile fatty acids }^{\mathrm{q}}\right)\end{array}$ & $\begin{array}{l}\text { Unknow } \\
\mathrm{n}(>14)\end{array}$ & (Orem et al., 2014) \\
\hline $\begin{array}{l}\text { Denver- } \\
\text { Julesberg (CO) }\end{array}$ & Produced (Unknown) & $\begin{array}{l}\text { LC-TOF-MS (polyethylene } \\
\text { glycols), GC-FID (total petroleum } \\
\text { hydrocarbons) }\end{array}$ & 4 & $\begin{array}{l}\text { (Rosenblum et al., } \\
\text { 2016) }\end{array}$ \\
\hline $\begin{array}{l}\text { Marcellus } \\
\text { (Greene } \\
\text { County, PA) }\end{array}$ & $\begin{array}{l}\text { Produced water (18 } \\
\text { months) }\end{array}$ & $\begin{array}{l}\text { GCxGC-TOF-MS (aliphatic, } \\
\text { cycloaliphatic, and aromatic } \\
\text { compounds, and PAHs) }\end{array}$ & 1 & (Strong et al., 2013) \\
\hline Unknown (TX) & Unknown & $\begin{array}{l}\text { GC-MS (VOCs }{ }^{\mathrm{q}, \mathrm{l}}, \text { SVOCs), } \\
\text { LCMS-IT-TOF (surfactant), IC } \\
\text { (organic acids }^{\mathrm{q}} \text { ) }\end{array}$ & 3 & $\begin{array}{l}\text { (Thacker et al., } \\
\text { 2015) }\end{array}$ \\
\hline $\begin{array}{l}\text { Denver- } \\
\text { Julesberg (CO), } \\
\text { Barnett (TX), } \\
\text { PA, NV, LA } \\
\end{array}$ & $\begin{array}{l}\text { Flowback and } \\
\text { Produced }\end{array}$ & $\begin{array}{l}\text { LC-TOF-MS (ethoxylated } \\
\text { surfactants } \text { ) }\end{array}$ & $12^{\wedge}$ & $\begin{array}{l}\text { (Thurman et al., } \\
\text { 2014) }\end{array}$ \\
\hline Marcellus (PA) & $\begin{array}{l}\text { Flowback, Produced } \\
\text { and } \\
\text { Flowback/Produced } \\
\text { Mixture }\end{array}$ & 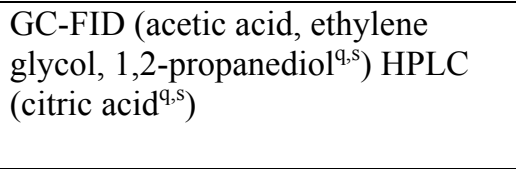 & 10 & (Wolford, 2011) \\
\hline Marcellus (WV) & $\begin{array}{l}\text { Flowback (Day 0, } 7 \\
14,35 \text { ) }\end{array}$ & $\begin{array}{l}\text { Unreported, listed as EPA certified } \\
\text { labs }\end{array}$ & 13 & (Ziemkiewicz, 2013) \\
\hline Marcellus (WV) & Flowback & $\begin{array}{l}\text { GC-MS }\left(\mathrm{VOCs}^{\mathrm{q}, \mathrm{s}}\right) \text { GC-FID } \\
\left(\text { petroleum hydrocarbons }^{\mathrm{q}, \mathrm{s}}\right) \mathrm{MBA}^{*} \\
\left(\text { surfactants }^{\mathrm{q}, \mathrm{s}}\right)\end{array}$ & 13 & $\begin{array}{l}\text { (Ziemkiewicz and } \\
\text { He, 2015) }\end{array}$ \\
\hline
\end{tabular}


A number of known and suspect additives have been identified in flowback and produced

167

168

169

170

171

172

173

174

175

176

177

178

179

180

181

182

183

184

185

186

187

188

waters, although not all studies had access to the corresponding list of additives or the HVHF fluid alone prior to injection (Cluff et al., 2014; Hayes, 2009; Hoelzer et al., 2016; Lester et al., 2015; Orem et al., 2014; Rosenblum et al., 2016; Strong et al., 2013; Thacker et al., 2015; Wolford, 2011). Quantitative analyses for known organic additives are still limited by a lack of standards and standard methods and many compounds can only be putatively identified. Several surfactants/dispersants have been identified including ethoxylated alcohols (Cluff et al., 2014;

Lester et al., 2015; Thurman et al., 2014), ethoxylated phenols (Orem et al., 2014), glycols (Hayes, 2009; Orem et al., 2014; Robert Wolford, 2011; Rosenblum et al., 2016), alkyl amines (Thacker et al., 2015), cocamide compounds (Ferrer and Thurman, 2015b; Thacker et al., 2015), 2-butoxyethanol (Thacker et al., 2015), and bulk anionic surfactants (as methyl blue active substances) (Ziemkiewicz and He, 2015). Of these surfactants, only ethylene glycol and propylene glycol were reported quantitatively and neither of these studies appear in the peer reviewed literature (Hayes, 2009; Wolford, 2011). The biocides alkyl dimethyl benzyl ammonium chloride, glutaraldehyde, and hexahydro-1,3,5-trimethyl-1,3,5-triazine-2-thione have been detected but only the latter was quantified (Ferrer and Thurman, 2015b; Orem et al., 2014). The triazine biocide was initially detected in flowback at very high levels $\left(1.5 \mathrm{mg} \mathrm{L}^{-1}\right)$ but returned to very low levels $\left(10 \mu \mathrm{g} \mathrm{L}^{-1}\right)$ within one week of well operation (Orem et al., 2014). Phthalates have been identified in several flowback and produced water samples (Hayes, 2009; Hoelzer et al., 2016; Lester et al., 2015; Maguire-Boyle and Barron, 2014; Orem et al., 2014). In quantitative analyses of phthalates, di-n-octyl-phthalate peaked in Marcellus shale early flowback (5600 $\left.\mu \mathrm{g} \mathrm{L}^{-1}\right)$ and rapidly declined (Orem et al., 2014), but no clear pattern was observed in nineteen Marcellus shale well time series for diethyl phthalate, di-n-butyl phthalate, 
189

190

191

192

193

194

195

196

197

di-n-octyl-phthalate, or bis-(2-ethylhexyl) phthalate (Hayes, 2009).

Citric acid, used for iron control, was reported in Marcellus flowback samples at high concentrations $\left(9,53\right.$, and $\left.70 \mathrm{mg} \mathrm{L}^{-1}\right)$ but was not identified in any produced water samples within the same study (Wolford, 2011). 2,2,4-trimethyl-1,3,-pentanediol (solvent) and tridecane (fuel component) were also traced in a Marcellus shale well across flowback and produced waters, and while both peaked around the second day of flowback, both remained above $200 \mu \mathrm{g}$ $\mathrm{L}^{-1}$ in produced waters (Orem et al., 2014). The gelling agent guar gum was analyzed for but neither detected nor quantified in twenty-two Denver-Julesberg flowback and produced water samples (Ferrer and Thurman, 2015b). Bisphenol F and 2-butoxy ethanol were reported in a Texas produced water sample (Thacker et al., 2015), and a number of other additives have been reported non-quantitatively in several shale plays including a dioctadecyl ester of phosphate (lubricant), and some fluorinated organic compounds (possible flowpath tracers) (Hoelzer et al., 2016; Maguire-Boyle and Barron, 2014).

\subsection{Geogenic organic compounds from additives and/or shale}

Ultrahigh resolution mass spectrometry has been used to identify more than 30,000 organic compounds in shale oil. ${ }^{20,22}$ Although shale gas is more aged than shale oil and likely contains fewer organic compounds, interactions of the fracturing fluid with shale likely extracts a very large number of geogenic organic compounds from both oil and gas producing wells.

Combined with a number of petrogenic additives such as petroleum distillates, kerosene, BTEX, mixed alkanes, and naphthalenes, many geogenic compounds may be present in any given flowback fluid or produced water. Indeed, more than a thousand geogenic organic compounds have been identified in flowback and produced waters using GC-FID, GC-MS, and GCxGC- 
212 TOF-MS (Hoelzer et al., 2016; Maguire-Boyle and Barron, 2014; Orem et al., 2014; Strong et

213 al., 2013), but only twenty four of these compounds have been reported quantitatively above the

214 limit of detection in the peer reviewed literature (Akob et al., 2015; Lester et al., 2015;

215 Ziemkiewicz and He, 2015; Ziemkiewicz, 2013). Reported concentrations of these quantifiable

216 organic compounds are given in supplemental online materials (Table S1, Figure S1), including

217 data from two non-peer reviewed sources (Hayes, 2009; Wolford, 2011). Dissolved methane as

218 well as other light gases including ethane, propane, and butane will not be discussed here as they

219 are by default present in productive wells. Overall, extractable hydrocarbons decreased in

220 concentration during flowback and were lowest in produced water in a large number of analyzed

221 samples (Orem et al., 2014). In broad spectrum reports of organic compounds in flowback and

222 produced waters using various types of gas chromatography, aliphatic compounds were the

223 dominant class identified (Hoelzer et al., 2016; Maguire-Boyle and Barron, 2014; Orem et al.,

224 2014; Strong et al., 2013). Out of 986 compounds tentatively identified using GCxGC-TOF-MS

225 in a Marcellus shale produced water, $61 \%$ of the identified compounds were aliphatic, and $24 \%$

226 were cycloaliphatic (Strong et al., 2013). Aromatic compounds represented 13\% of the

227 remaining compounds. PAHs accounted for $2 \%$ in this Marcellus shale produced water, and a

228 substantial number of aromatic compounds and PAHs were also identified by other broad

229 spectrum reports of organic compounds (Hoelzer et al., 2016; Maguire-Boyle and Barron, 2014;

230 Orem et al., 2014). A new analytical technique has been developed for quantification of PAHs

231 and other SVOCs in HVHF wastewater pairing solid-phase extraction with GC-MS (Regnery et

232 al., 2016).

233 BTEX compounds were both the most frequently analyzed organic compounds in

234 flowback and produced water and the most frequently detected organic compounds above 
235 detection limits (Figure 2). In the Marcellus shale, BTEX concentrations were highest in

236 flowback over the first 90 days, but were detectable at low concentrations in produced waters

237 even several years after the initial HVHF event. Toluene, ethylbenzene, and xylene

238 concentrations in flowback were up to two orders of magnitude lower than benzene quantified

239 concurrently. Fayetteville, Burket, and Denver-Julesberg samples were only analyzed in early

240 flowback and had similar levels to the Marcellus shale (Akob et al., 2016; Hoelzer et al., 2016;

241 Lester et al., 2015). In the Permian basin, produced water after 130-441 days of operation had

242 consistently high levels of benzene, toluene, and ethylbenzene, of hundreds of $\mathrm{mg} \mathrm{L}^{-1}$, while

243 xylenes concentration were three orders of magnitude lower, similar to Marcellus flowback

244 (Khan et al., 2016). High BTEX concentrations found in the Permian could be associated with oil

245 production compared to the generally dry Marcellus shale gas. A clear distinction was made in a

246 side by side comparison of BTEX in a dry and a wet Marcellus shale gas; wet gas concentrations

247 were two orders of magnitude higher for all ions than dry gas, peaking in wet gas seven days

248 after HVHF (benzene $=375 \mu \mathrm{g} \mathrm{L}{ }^{-1}$, toluene $=2,100 \mu \mathrm{g} \mathrm{L}^{-1}$, xylenes $(\mathrm{m}, \mathrm{p})=2,400 \mathrm{ug} \mathrm{L}{ }^{-1}$ )

249 [ethylbenzene not reported] (Ziemkiewicz, 2013).

250 Aromatic compounds including polycyclic aromatic hydrocarbons have been

251 quantitatively reported in a number of studies. Phenol, 2-methylphenol, 3\&4-methylphenol, 2,4

252 dimethylphenol, 2-methylnaphthalene, phenanthrene, and pyrene were all quantified in a

253 composite Denver-Julesberg basin flowback sample (Lester et al., 2015) and in Marcellus shale

254 flowback and produced waters (Hayes, 2009). 1,2,4-trimethylbenzene and isopropylbenzene

255 were quantified in Fayetteville flowback fluids and Marcellus shale flowback and produced

256 waters (Hoelzer et al., 2016). New Albany shale produced waters also frequently contained alkyl

257 napthalenes, phenanthrenes, and pyrene (Orem et al., 2014). Alkylated benzenes and alkylated 
258 naphthalenes were identified but not quantified in Barnett and Marcellus shales (Maguire-Boyle

259 and Barron, 2014). Methyl phenol and dimethylphenol were detected in much higher

260 concentrations in a composite flowback sample from the Denver-Julesberg basin than PAHs

261 (150-830 ug L ${ }^{-1}$ vs. $<10$ ug L $\left.{ }^{-1}\right)$ (Lester et al., 2015), but similar concentration ranges of both the

262 phenolic and PAH compounds were observed in the Marcellus (Hayes, 2009). A number of

263 oxygen containing resins/asphaltenes were identified in Marcellus, Barnett and Eagle Ford shale

264 produced waters (Maguire-Boyle and Barron, 2014).

265 Polychlorinated biphenyls (PCBs) and pesticides were analyzed for the Hayes report

266 (Hayes, 2009) in nineteen wells over the first ninety days after HVHF, but were only detected

267 sporadically in very low concentrations and the report concluded that testing for these

268 compounds in future wastewater analyses was unnecessary. These compounds have not been

269 specifically targeted in any other study, and no evidence has been provided for a potential source

270 for these compounds in fracturing additives. 

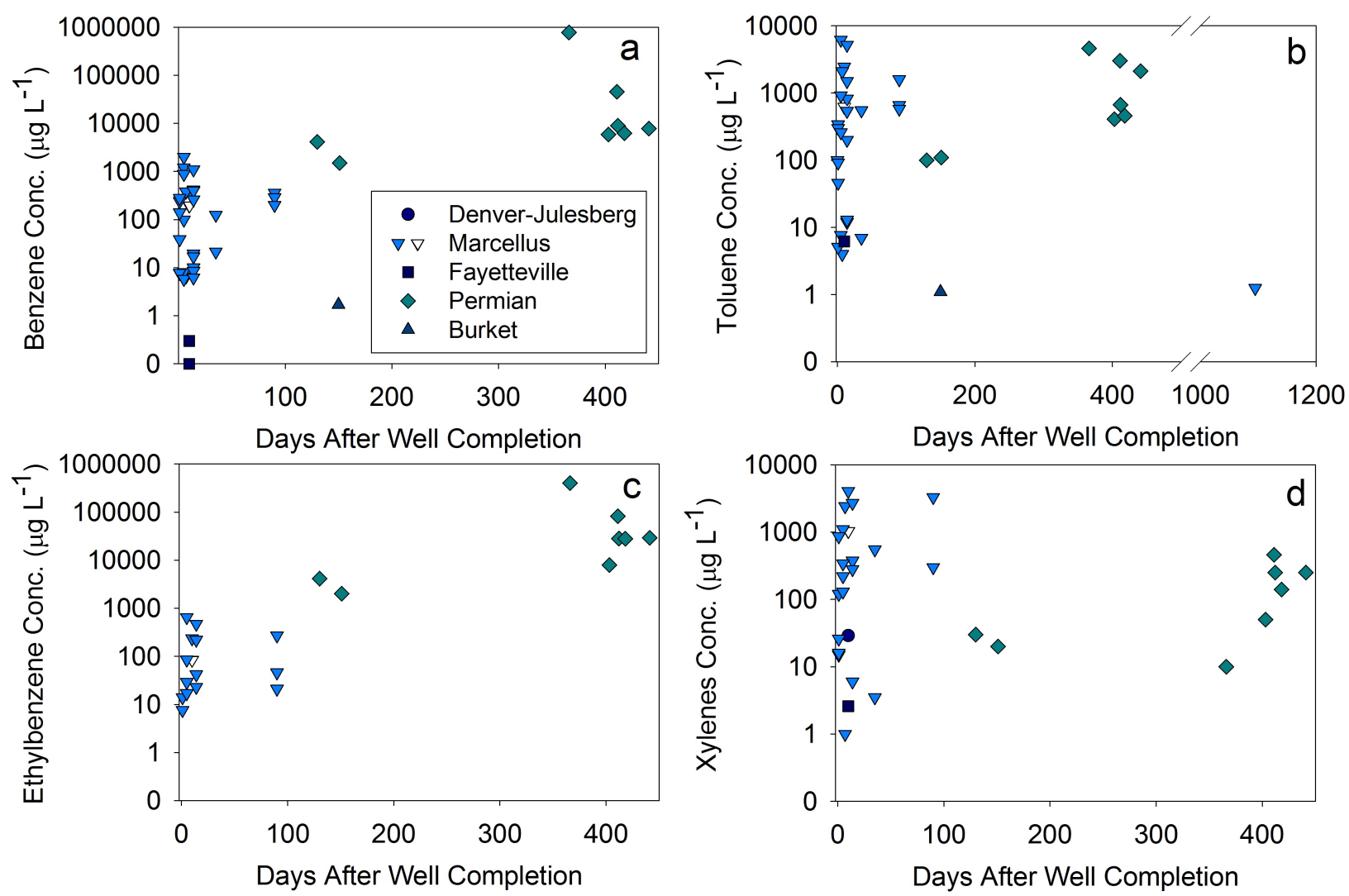

272 Figure 2. Concentrations (log scale) of benzene (a), toluene (b), ethylbenzene (c), and xylene (d) 273 in flowback and produced water samples by days after HVHF well completion from literature 274 (Akob et al., 2015; Hayes, 2009; Hoelzer et al., 2016; Khan et al., 2016; Lester et al., 2015; 275 Wolford, 2011; Ziemkiewicz, 2013; Ziemkiewicz and He, 2015). Open triangles indicate mean of 13 Marcellus samples (Ziemkiewicz and He, 2015), colored triangles represent individual data points. Fayetteville samples are shown on day 10 for comparison but were collected within the first three weeks (Hoelzer et al., 2016). Note: benzene and ethylbenzene are given on a different scale than toluene and xylenes.

\subsection{Transformation products of organic constituents}

283 chemical or biological processes. Indeed, specific additives are designed to chemically transform

284 and "break" polymers in the fracturing fluid to reduce surface tension before flowback begins

285 (Stringfellow et al., 2014). Despite the use of biocides, high bacterial cell counts have been identified both in the injected fluids and in flowback and produced waters (Cluff et al., 2014; 
287

288

289

290

291

292

293

294

295

296

297

298

299

300

301

302

303

304

305

306

307

308

309

Mohan et al., 2014; Murali Mohan et al., 2013a). Hence, a combination of physical, chemical and biologically mediated reactions ultimately drive the transformation of organic compounds in these fluids (Elsner and Hoelzer, 2016; Hoelzer et al., 2016).

A number of small organic acids are produced through microbial transformation under the anaerobic conditions frequently observed in HVHF wastewater via fermentation (Müller, 2008). Small organic acids were analyzed in a handful of studies, although not all report quantitative results. Acetate was measured in seven studies (Figure 3), formate in three (Akob et al., 2015; Strong et al., 2013; Thacker et al., 2015), and citrate (Wolford, 2011), lactate, propionate, butyrate, and pyruvate (Akob et al., 2015) were each analyzed in one study. Acetate, propionate, and butyrate were measured in the Hayes dataset with high method detection limits $\left(10 \mathrm{mg} \mathrm{L}^{-1}\right)$ but are not included due to questionable reliability (Hayes, 2009). Acetate and other organic acids are likely produced during the anaerobic degradation of additives and potentially geogenic substances as hydrocarbons are degraded to acetate under anaerobic conditions (e.g., Callbeck et al., 2013). Indeed, fermentative classes of bacteria capable of producing organic acids were identified in flowback samples where acetate was identified (Cluff et al., 2014; Murali Mohan et al., 2013b). Acetate concentrations were highest in flowback samples, presumably due to the high concentrations of degradable organic additives such as ethoxylates, guar gum, and glycols. The highest concentration of acetate observed $\left(1600 \mathrm{mg} \mathrm{L}^{-1}\right)$ was in a composite flowback sample, and was three times higher than the next highest sample and an order of magnitude higher than most flowback samples (Lester et al., 2015). Aeration of flowback fluid resulted in acetate decreasing below detection limits, which is not surprising as fermentation would no longer be occurring and any acetate previously produced would likely be readily mineralized in situ under aerobic conditions (Murali Mohan et al., 2013b). Produced 
310 water samples contained much lower acetate concentrations. In 14 Marcellus shale produced

311 water samples (Figure 3, Produced*), the mean acetate concentration was $10.6 \mathrm{mg} \mathrm{L}^{-1}$, but the

312 range was not reported (Orem et al., 2014). In 16 other produced water samples, the mean acetate

313 concentration was $7.0 \mathrm{mg} \mathrm{L}^{-1}$. Formate was not detected in two of the three studies in which it

314 was analyzed, and in those where it was not detected acetate was also absent (Strong et al., 2013;

315 Thacker et al., 2015). Butyrate was not detected in any of the 13 produced water samples it was

316 analyzed in, but propionate, lactate, formate, and pyruvate were detected in produced water

317 samples at low levels $\left(<4 \mathrm{mg} \mathrm{L}^{-1}\right.$ each) and acetate in slightly higher concentrations (mean 5.8

$318 \mathrm{mg} \mathrm{L}^{-1}$ ). These are indications for continued bacterial activity (Akob et al., 2015).

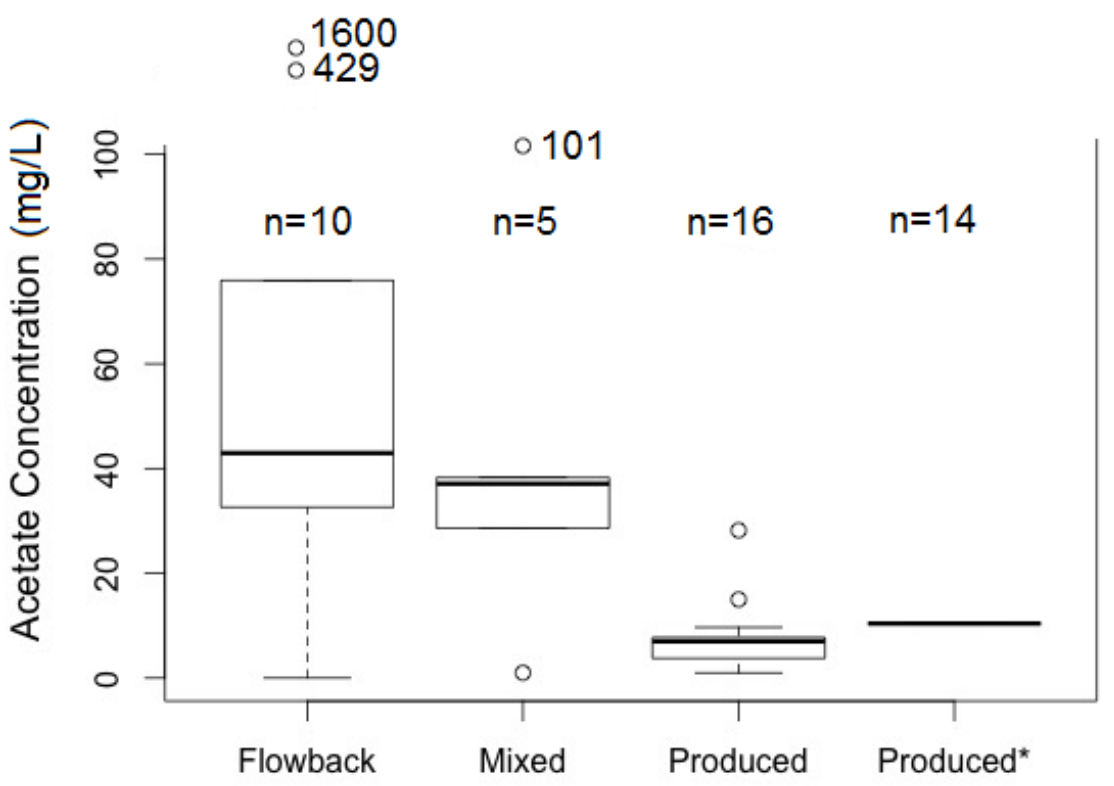

Figure 3. Boxplot of acetate/acetic acid concentrations in quantified samples reported in literature (Akob et al., 2015; Lester et al., 2015; Murali Mohan et al., 2013b; Orem et al., 2014; Strong et al., 2013; Thacker et al., 2015; Wolford, 2011). Box gives median and 25th and 75th percentiles, whisker represent 90th percentile, and individual points show outliers. Acetate values below detection for one produced and two HVHF wastewater samples were not included in the box plot (Strong et al., 2013; Thacker et al., 2015). Mixed is a combination of flowback and produced water (Wolford, 2011). Produced* represents mean of 14 samples reported by (Orem et al., 2014). 


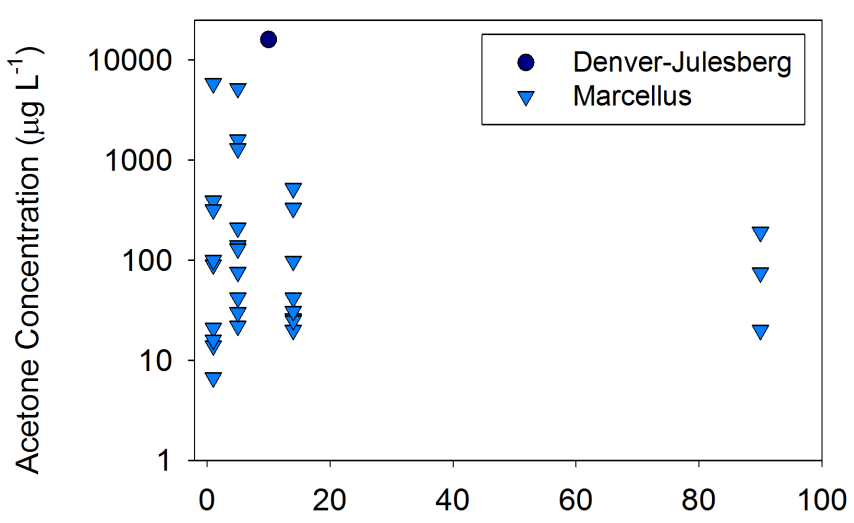

Days After Well Completion

Figure 4. Acetone concentrations in flowback and produced water to 90 days compiled from literature values (Akob et al., 2015; Hayes, 2009; Hoelzer et al., 2016; Lester et al., 2015; Wolford, 2011; Ziemkiewicz, 2013; Ziemkiewicz and $\mathrm{He}, 2015)$. Acetone analyses were not performed on samples collected more than 90 days after HVHF well completion.

Acetone in flowback may originate from its use as an additive, may be a transformation product via anaerobic fermentation via pyruvate (Rosenfeld and Simon, 1950), or may be associated with both sources. Acetone concentrations were highly variable in flowback samples (most ND, median $90 \mu \mathrm{g} \mathrm{L^{-1 }}$ in positive detections, mean of $1,060 \mu \mathrm{g} \mathrm{L}{ }^{-1}$ in $\mathrm{n}=37$ positive detections) and acetone was not measured in any samples after 90 days (Figure 4). The highest observed concentration was measured in a composite flowback sample $\left(16,000 \mu \mathrm{g} \mathrm{L} \mathrm{L}^{-1}\right)$ (Lester et al., 2015), and several other flowback samples had acetone concentrations ranging from $10^{2}-10^{3}$ $\mu g \mathrm{~L}^{-1}$ (Hayes, 2009). Interestingly, in at least one supply water sample (used for mixing to make HVHF fluid), acetone concentrations were even higher than in flowback (Hayes, 2009), suggesting that this supply water was likely a recycled fluid that contained high levels of acetone as an additive or degradable organic additives that underwent fermentation to form acetone. In a simulated bioreactor "spill" of HVHF fluids, acetone was produced as a degradation product (see Section 4.2) (Kekacs et al., 2015).

$19 \%$ of the 404 identified organic compounds in Fayetteville shale flowback fluid and 
347 produced waters using GCxGC-TOF-MS were suspected to be formed through subsurface

348 reactions (Hoelzer et al., 2016). Many of these compounds included carbonyl groups (Hoelzer et

349 al., 2016) that may indicate degradation of geopolymers or hydrolysis products of delayed-

350 release acids used as breakers (Hoelzer et al., 2016; Orem et al., 2014, 2010). In Marcellus shale

351 produced waters, 2,2,4-trimethyl-1,3-pentanediol was identified at high concentrations (130 -

$\left.352500 \mu \mathrm{g} \mathrm{L}^{-1}\right)$ in flowback and remained at those concentrations in the produced waters even 234

353 days after HVHF (Orem et al., 2014). This compound has not been identified as an additive

354 previously, but a related compound, 2,2,4-trimethyl-1,3- pentanediol monoisobutyrate, has been

355 used industrially as a solvent and may potentially be related to the source of this derivative

356 (Orem et al., 2014). A direct transformation product of the known additive, azobis

357 (isobutyronitrile), tetramethylsuccinonirile was identified by GCxGC-TOF-MS in Fayetteville

358 shale produced waters (Hoelzer et al., 2016). Dimerization and trimerization of the frequently

359 used biocide glutaraldehyde under the variable salinity, temperature, and pressure conditions

360 reflecting a shale gas well has been tested under laboratory conditions (Kahrilas et al., 2016), but

361 has not been observed in flowback and produced waters (Ferrer and Thurman, 2015b).

362 Additionally, hydroxylated phenols identified in flowback fluids are likely degradation products

363 of alkylphenol ethoxylate additives (Hoelzer et al., 2016).

364 A number of studies have putatively identified halogenated organic compounds in

365 flowback and produced waters that are much more diverse than the limited number of known

366 halogenated additives (Table 2). Perfluorinated organic compounds identified in the Eagle Ford

367 shale produced waters were suggested to be tracers used for reservoir mapping (Maguire-Boyle

368 and Barron, 2014). Methylene chloride is the only explicitly disclosed halogenated organic

369 compound identified in flowback and produced waters, but four additional halogenated organic 
compounds (chloromethyl propanoate, chloromethyl pentanoate, chloromethyl hexanoate,

371 chloromethyl octanoate) identified by Hoelzer and colleagues are suspected HVHF additives

372 (Hoelzer et al., 2016). Four studies have identified a number of additional halogenated organic

373 compounds that are likely transformation products and several potential mechanisms for the

374 formation of these compounds are hypothesized (Hayes, 2009; Hoelzer et al., 2016; Luek et al.,

375 2017; Maguire-Boyle and Barron, 2014). Maguire-Boyle and Barron (2014) identified the

376 corresponding non-halogenated aliphatic compound for each halogenated compound and

377 suggested that the halide salts or free halogens created during oxidative treatments could cause

378 the observed halogenation (Maguire-Boyle and Barron, 2014). Similarly, Hoelzer and colleagues

379 indicated radicalic substitution, nucleophilic substitution, and electrophilic addition in the

380 presence of halides and free halogen species as the proposed halogenation mechanisms (Hoelzer

381 et al., 2016). In streambed sediments downstream of a deep well injection facility, several

382 halogenated organic compounds including 1,54-dibromotetrapentacontane were identified (Orem

383 et al., 2017).

Table 2. Halogenated organic compounds identified in flowback and produced waters. Italicized compounds are explicit and suspect fracturing fluid additives. Note: Compounds identified in Hayes (2009) rely on EPA methods with quantification using reference standards; Hoelzer et al., (2016) and Maguire-Boyle and Barron (2014) match ions using spectral libraries and report confidence in assignment in their supplemental materials. Halogenated chemical formulas in

\begin{tabular}{|l|l|l|l|}
\hline Compound & $\begin{array}{l}\text { Molecular } \\
\text { Formula }\end{array}$ & Method & Source \\
\hline Chloromethane & $\mathrm{CH}_{3} \mathrm{Cl}$ & $\begin{array}{l}\text { GC/MS EPA Method } \\
\text { SW846 8260B }\end{array}$ & Hayes 2009 \\
\hline Dichloromethane & $\mathrm{CH}_{2} \mathrm{Cl}_{2}$ & $\begin{array}{l}\text { GC/MS EPA Method } \\
\text { SW846 8260B }\end{array}$ & Hayes 2009 \\
\hline Dichloromethane & $\mathrm{CH}_{2} \mathrm{Cl}_{2}$ & GCxGC-TOF-MS & Hoelzer et al., 2016 \\
\hline Dichloromethane & $\mathrm{CH}_{2} \mathrm{Cl}_{2}$ & GC/MS & Maguire-Boyle and Barron 2014 \\
\hline Trichloromethane & $\mathrm{CHCl}_{3}$ & GC/MS & Maguire-Boyle and Barron 2014 \\
\hline Tetrachloroethene & $\mathrm{C}_{2} \mathrm{Cl}_{4}$ & $\begin{array}{l}\text { GC/MS EPA Method } \\
\text { SW846 8260B }\end{array}$ & Hayes 2009 \\
\hline
\end{tabular}




\begin{tabular}{|c|c|c|c|}
\hline 1,1-dichloroethane & $\mathrm{C}_{2} \mathrm{H}_{4} \mathrm{Cl}_{2}$ & GC/MS & Maguire-Boyle and Barron 2014 \\
\hline 1,1'-oxybis[1,1]-dichloromethane & $\mathrm{C}_{2} \mathrm{H}_{4} \mathrm{Cl}_{2} \mathrm{O}$ & GC/MS & Maguire-Boyle and Barron 2014 \\
\hline Chloromethyl propanoate & $\mathrm{C}_{4} \mathrm{H}_{7} \mathrm{ClO}_{2}$ & GCXGC-TOF-MS & Hoelzer et al., 2016 \\
\hline bis(2-chloroethyl) ether & $\mathrm{C}_{4} \mathrm{H}_{8} \mathrm{Cl}_{2} \mathrm{O}$ & $\begin{array}{l}\text { GC/MS EPA Method } \\
\text { SW846 8260B }\end{array}$ & Hayes 2009 \\
\hline 1-chloro-5-iodo-pentane & $\mathrm{C}_{5} \mathrm{H}_{10} \mathrm{ClI}$ & GCxGC-TOF-MS & Hoelzer et al., 2016 \\
\hline 1,1-dimethyl-3-chloropropanol & $\mathrm{C}_{5} \mathrm{H}_{11} \mathrm{ClO}$ & GCxGC-TOF-MS & Hoelzer et al., 2016 \\
\hline Hexachlorobenzene & $\mathrm{C}_{6} \mathrm{Cl}_{6}$ & $\begin{array}{l}\text { GC/MS EPA Method } \\
\text { SW846 8270C }\end{array}$ & Hayes 2009 \\
\hline 2-(chloromethyl) tetrahydropyran & $\mathrm{C}_{6} \mathrm{H}_{11} \mathrm{ClO}$ & GCxGC-TOF-MS & Hoelzer et al., 2016 \\
\hline 2-chlorocyclohexanol & $\mathrm{C}_{6} \mathrm{H}_{11} \mathrm{ClO}$ & GCxGC-TOF-MS & Hoelzer et al., 2016 \\
\hline Chloromethyl pentanoate & $\mathrm{C}_{6} \mathrm{H}_{11} \mathrm{ClO}_{2}$ & GCXGC-TOF-MS & Hoelzer et al., 2016 \\
\hline 1-chloro-3,3-dimethyl-butane & $\mathrm{C}_{6} \mathrm{H}_{13} \mathrm{Cl}$ & GCxGC-TOF-MS & Hoelzer et al., 2016 \\
\hline 1,2,3-trichlorobenzene & $\mathrm{C}_{6} \mathrm{H}_{3} \mathrm{Cl}_{3}$ & $\begin{array}{l}\text { GC/MS EPA Method } \\
\text { SW846 8260B }\end{array}$ & Hayes 2009 \\
\hline 1,2,4-trichlorobenzene & $\mathrm{C}_{6} \mathrm{H}_{3} \mathrm{Cl}_{4}$ & $\begin{array}{l}\text { GC/MS EPA Method } \\
\text { SW846 8260B }\end{array}$ & Hayes 2009 \\
\hline 1,4-dichlorobenzene & $\mathrm{C}_{6} \mathrm{H}_{4} \mathrm{Cl}_{2}$ & $\begin{array}{l}\text { GC/MS EPA Method } \\
624\end{array}$ & Hoelzer et al., 2016 \\
\hline 2,6-dichlorophenol & $\mathrm{C}_{6} \mathrm{H}_{4} \mathrm{Cl}_{2} \mathrm{O}$ & $\begin{array}{l}\text { GC/MS EPA Method } \\
\text { SW846 8270C }\end{array}$ & Hayes 2009 \\
\hline $\begin{array}{l}\text { 2,4-dichloro-5-oxo-2-hexenedioic } \\
\text { acid }\end{array}$ & $\mathrm{C}_{6} \mathrm{H}_{4} \mathrm{Cl}_{2} \mathrm{O}_{5}$ & GC/MS & Maguire-Boyle and Barron 2014 \\
\hline Dichlorophenol & $\mathrm{C}_{6} \mathrm{H}_{4} \mathrm{ClO}$ & $\begin{array}{l}\text { GC/MS EPA Method } \\
\text { SW846 8260B }\end{array}$ & Hayes 2009 \\
\hline $\begin{array}{l}\text { 2,2-dichloro-3,6-dimethyl-1-Oxa-2- } \\
\text { silacyclohexa-3,5-diene }\end{array}$ & $\mathrm{C}_{6} \mathrm{H}_{8} \mathrm{Cl}_{2} \mathrm{OSi}$ & GC/MS & Maguire-Boyle and Barron 2014 \\
\hline $\begin{array}{l}\text { 3-chloro-1,1,2,2-tetramethyl- } \\
\text { cyclopropane }\end{array}$ & $\mathrm{C}_{7} \mathrm{H}_{13} \mathrm{Cl}$ & GCxGC-TOF-MS & Hoelzer et al., 2016 \\
\hline Chloromethyl hexanoate & $\mathrm{C}_{7} \mathrm{H}_{14} \mathrm{ClO}_{2}$ & GCXGC-TOF-MS & Hoelzer et al., 2016 \\
\hline Chloromethyl octanoate & $\mathrm{C}_{9} \mathrm{H}_{17} \mathrm{ClO}_{2}$ & GCXGC-TOF-MS & Hoelzer et al., 2016 \\
\hline 1-chlorohexadecane & $\mathrm{C}_{16} \mathrm{H}_{33} \mathrm{Cl}$ & GC/MS & Maguire-Boyle and Barron 2014 \\
\hline 1-chlorooctadecane & $\mathrm{C}_{18} \mathrm{H}_{37} \mathrm{Cl}$ & GC/MS & Maguire-Boyle and Barron 2014 \\
\hline Trichlorodocosylsilane & $\mathrm{C}_{22} \mathrm{H}_{45} \mathrm{Cl}_{3} \mathrm{Si}$ & GC/MS & Maguire-Boyle and Barron 2014 \\
\hline 1-chloroheptacosane & $\mathrm{C}_{27} \mathrm{H}_{55} \mathrm{Cl}$ & GC/MS & Maguire-Boyle and Barron 2014 \\
\hline Bromomethane & $\mathrm{CH}_{3} \mathrm{Br}$ & $\begin{array}{l}\text { GC/MS EPA Method } \\
\text { SW846 8260B }\end{array}$ & Hayes 2009 \\
\hline Tribromomethane & $\mathrm{CHBr}_{3}$ & $\begin{array}{l}\text { GC/MS EPA Method } \\
\text { SW846 8260B }\end{array}$ & Hayes 2009 \\
\hline 2-bromo-hexane & $\mathrm{C}_{6} \mathrm{H}_{13} \mathrm{Br}$ & GCxGC-TOF-MS & Hoelzer et al., 2016 \\
\hline 1-bromo-2-methyl-cyclohexane & $\mathrm{C}_{7} \mathrm{H}_{13} \mathrm{Br}$ & GCxGC-TOF-MS & Hoelzer et al., 2016 \\
\hline 4-bromoheptane & $\mathrm{C}_{7} \mathrm{H}_{15} \mathrm{Br}$ & GCxGC-TOF-MS & Hoelzer et al., 2016 \\
\hline $\begin{array}{l}\text { 2-piperidinone, N-[4-bromo-n- } \\
\text { butyl] }\end{array}$ & $\mathrm{C}_{9} \mathrm{H}_{16} \mathrm{BrNO}$ & GCxGC-TOF-MS & Hoelzer et al., 2016 \\
\hline $\begin{array}{l}\text { 2-bromo- } \\
\text { tricyclo[3.3.1.1(3,7)]decane }\end{array}$ & $\mathrm{C}_{10} \mathrm{H}_{15} \mathrm{Br}$ & GCxGC-TOF-MS & Hoelzer et al., 2016 \\
\hline 3-bromo-cyclodecene & $\mathrm{C}_{10} \mathrm{H}_{17} \mathrm{Br}$ & GCxGC-TOF-MS & Hoelzer et al., 2016 \\
\hline 4,5-dibromo-, $\left(\mathrm{R}^{*}, \mathrm{R}^{*}\right)$-decane & $\mathrm{C}_{10} \mathrm{H}_{20} \mathrm{Br}_{2}$ & GCxGC-TOF-MS & Hoelzer et al., 2016 \\
\hline 1,12-dibromododecane & $\mathrm{C}_{12} \mathrm{H}_{24} \mathrm{Br}_{2}$ & GC/MS & Maguire-Boyle and Barron 2014 \\
\hline
\end{tabular}




\begin{tabular}{|l|l|l|l|}
\hline 14-bromo-1-tetradecene & $\mathrm{C}_{14} \mathrm{H}_{27} \mathrm{Br}$ & GC/MS & Maguire-Boyle and Barron 2014 \\
\hline 1-bromopentadecane & $\mathrm{C}_{15} \mathrm{H}_{31} \mathrm{Br}$ & GC/MS & Maguire-Boyle and Barron 2014 \\
\hline 7-bromomethyl-pentadec-7-ene & $\mathrm{C}_{16} \mathrm{H}_{31} \mathrm{Br}$ & GCxGC-TOF-MS & Hoelzer et al., 2016 \\
\hline 1-bromohexadecane & $\mathrm{C}_{16} \mathrm{H}_{33} \mathrm{Br}$ & GC/MS & Maguire-Boyle and Barron 2014 \\
\hline 1-bromooctadecane & $\mathrm{C}_{18} \mathrm{H}_{37} \mathrm{Br}$ & GC/MS & Maguire-Boyle and Barron 2014 \\
\hline 1,54-dibromotetrapentacontane & $\mathrm{C}_{54} \mathrm{H}_{108} \mathrm{Br}_{2}$ & GC/MS & Maguire-Boyle and Barron 2014 \\
\hline 3-iodo-propanoic acid, & $\mathrm{C}_{3} \mathrm{H}_{5} \mathrm{IO}_{2}$ & GCxGC-TOF-MS & Hoelzer et al., 2016 \\
\hline 2-iodo-3-methyl-butane & $\mathrm{C}_{5} \mathrm{H}_{11} \mathrm{I}$ & GCxGC-TOF-MS & Hoelzer et al., 2016 \\
\hline 5-iodopentan-2-one & $\mathrm{C}_{5} \mathrm{H}_{9} \mathrm{IO}$ & GCxGC-TOF-MS & Hoelzer et al., 2016 \\
\hline 1-iodo-nonane & $\mathrm{C}_{9} \mathrm{H}_{19} \mathrm{I}$ & GCxGC-TOF-MS & Hoelzer et al., 2016 \\
\hline 1-iodo-2-methylundecane & $\mathrm{C}_{12} \mathrm{H}_{25} \mathrm{I}$ & GCxGC-TOF-MS & Hoelzer et al., 2016 \\
\hline 1-iodo-2-methylundecane & $\mathrm{C}_{12} \mathrm{H}_{25} \mathrm{I}$ & GC/MS & Maguire-Boyle and Barron 2014 \\
\hline 1-iodo-tetradecane & $\mathrm{C}_{14} \mathrm{H}_{29} \mathrm{I}$ & GCxGC-TOF-MS & Hoelzer et al., 2016 \\
\hline Bromodichloromethane & $\mathrm{CHBrCl}_{2}$ & GCxGC-TOF-MS & Hoelzer et al., 2016 \\
\hline $\begin{array}{l}\text { 1,3-dioxolane, 2-(3-bromo-5,5,5- } \\
\text { trichloro-2,2-dimethylpentyl) }\end{array}$ & $\mathrm{C}_{10} \mathrm{H}_{16} \mathrm{BrCl}_{3} \mathrm{O}_{2}$ & GCxGC-TOF-MS & Hoelzer et al., 2016 \\
\hline 1-bromo-11-iodoundecane & $\mathrm{C}_{11} \mathrm{H}_{22} \mathrm{BrI}$ & GC/MS & Maguire-Boyle and Barron 2014 \\
\hline
\end{tabular}

\section{Environmental Contamination}

\subsection{Contamination Events}

In the peer-reviewed literature, specific organic compounds have been identified in

395 surface water, sediments, and groundwater and have been linked to recent HVHF activities

396 (Cozzarelli et al., 2017; DiGiulio and Jackson, 2016a; Drollette et al., 2015; Gross et al., 2013;

397 Hildenbrand et al., 2016, 2015; Kassotis et al., 2014; Llewellyn et al., 2015; Orem et al., 2017).

398 These suspected contamination events were documented in the Bakken, Powder River Basin,

399 Marcellus, Permian, Barnett, and Denver-Julesberg basins, and next to a deep well injection

400 facility in West Virginia. The EPA has also published five "retrospective case studies"

401 investigating the impacts of HVHF on drinking water sources in five different locations between

402 2011-2013. (Retrospective Case Study in Killdeer, North Dakota: Study of the Potential Impacts

403 of Hydraulic Fracturing on Drinking Water Resources, 2015, Retrospective Case Study in

404 Northeastern Pennsylvania: Study of the Potential Impacts of Hydraulic Fracturing on Drinking

405 Water Resources, 2015, Retrospective Case Study in Southwestern Pennsylvania Study of the 
406

407

408

409

410

411

412

413

414

415

416

417

418

419

420

421

422

423

424

425

426

427

428

Potential Impacts of Hydraulic Fracturing on Drinking Water Resources, 2015, Retrospective

Case Study in the Raton Basin, Colorado: Study of the Potential Impacts of Hydraulic

Fracturing on Drinking Water Resources, 2015, Retrospective Case Study in Wise County,

Texas: Study of the Potential Impacts of Hydraulic Fracturing on Drinking Water Resources,

2015). Organic analyses have focused on additives and oil and gas related compounds; inorganic

tracers of HVHF including anions and metals have also been analyzed in these samples to

understand the potential contamination events.

The only large volume surface spill of HVHF wastewaters (11.4 million liters)

extensively analyzed for organic compounds and published in the literature occurred in Blacktail

Creek in North Dakota (Bakken formation) in January of 2015. Streamwater water and stream

bed sediment samples were collected in February and June of 2015 for a large number of organic and inorganic chemical analyses, biological, and toxicological analyses (Cozzarelli et al., 2017).

SVOCs including 1,3,5-trimethylbenzene, 1,2,3,4-tetramethylbenzene, and 1-methylnaphthalene were quantified in unfiltered water samples in a location of an oily sheen downstream from the spill location. However, these compounds were absent from filtered water samples, suggesting that many of these organic compounds might have been particle-bound. Trace SVOCs were identified in streambed sediment below reporting limits, but the authors suggested that the spill pathway over 10 s of meters of soil could have resulted in substantial sorption of hydrophobic organic compounds to soil prior to the spill entering the stream (Cozzarelli et al., 2017). Surface contamination of streamwaters and streambed sediments were also investigated outside of a deep well injection facility in West Virginia to determine if the large volumes of HVHF wastewater transported and unloaded on site resulted in contamination of the nearby environment (Akob et al., 2016; Orem et al., 2017). Extensive organic chemical analyses were performed targeting oil 
429 and gas compounds, known HVHF chemical additives, disinfection by-products, and additional

430 SVOCs including halogenated compounds (Orem et al., 2017). In streamwater, only tetra-hydro-

431 thiophene 1,1-dioxide, a compound used for cleaning natural gas, was consistently identified

432 downstream of the facility. In sediments, a complex mixture of organic compounds was

433 identified which included a number of halogenated organic compounds (trifluoracetate/alkanes

434 and halogenated alkanes), some of which have been identified previously in HVHF fluids

435 (Maguire-Boyle and Barron, 2014) and wastewaters while others are of unknown origin.

436 Although the results are complex and indicate possible broader contamination in the region

437 upstream of the facility, the distribution of organic compounds combined with inorganic analyses

438 (Akob et al., 2016) indicated clear environmental contamination from the HVHF wastewater

439 disposal facility.

440 The largest groundwater investigation to investigate the impacts of HVHF were

441 performed using private and public groundwater wells from aquifers overlying the Permian

442 ( $\mathrm{n}=42$ wells, multiple time points) and Barnett basins ( $\mathrm{n}=550, \mathrm{n}=100)$ (Fontenot et al., 2013;

443 Hildenbrand et al., 2016, 2015). Samples in both basins were analyzed using GC-MS and

444 headspace-gas chromatography (HS-GC) for a number of organic compounds identified in

445 HVHF fluid as well as others associated with oil and gas development. BTEX compounds,

446 chlorinated solvents (dichloromethane, chloroform), and low molecular weight alcohols were

447 detected in a number of Barnett region samples, with only toluene and methanol distributions

448 indicative of surface spills (Hildenbrand et al., 2015). Ethanol was found alongside high bromide

449 concentrations, another tracer of HVHF wastewater (Hildenbrand et al., 2015). Permian basin

450 groundwater wells were sampled at four time points, during which unconventional oil and gas

451 development increased significantly (Hildenbrand et al., 2016). Following the initial time point, 
452 ethanol and dichloromethane elevated significantly at an additional time point, and a number of

453 other organic compounds associated with oil and gas development and degradation (isopropyl

454 alcohol, propargyl alcohol, acetaldehyde, cyclohexane, toluene, xylene, ethylbenzene) that were

455 not present in the initial sampling campaign were identified (Hildenbrand et al., 2016). The

456 authors ultimately concluded that their findings indicated the transient nature of potential

457 contamination events in developed areas (Hildenbrand et al., 2016).

458 In northeastern Pennsylvania, groundwater samples were collected from private

459 residential wells (9-231 m depth) and analyzed for GC-amenable compounds (Drollette et al.,

460 2015). Gas related organic compounds were detected in 9 of 59 wells and diesel related organic

461 compounds were detect in 23 of 41 wells in highly variable concentrations (Drollette et al.,

462 2015). BTEX compounds were identified in 6 samples at trace levels below EPA drinking water

463 maximum contaminant level recommendations (Drollette et al., 2015). The highest

464 concentrations of observed organic compounds were identified within $1 \mathrm{~km}$ of a shale gas well as

465 well as in close proximity to a well that caused an environmental health and safety violation.

466 Based on geochemical fingerprinting tools, the authors concluded that the groundwater

467 contamination was likely due to surface spills associated with HVHF activities rather than via

468 subsurface contamination. Additionally, a disclosed additive, bis(2-ethylhexyl) phthalate, was

469 identified in the same two samples with the highest diesel related organic compounds

470 concentrations. Foaming was also observed in three residential drinking water wells in northern

471 Pennsylvania located in close proximity to HVHF wells (Llewellyn et al., 2015). Commercial

472 laboratories were unable to detect any compounds during this known contamination event other

473 than methane that exceeded regulatory drinking water standards and recommendations, but 2- 
474 butoxyethanol was identified in the foaming waters using GCxGC-qTOF-MS. 2-butoxyethanol is

475 an ingredient in the Airfoam HD additive frequently used during HVHF (Llewellyn et al., 2015).

476 In Weld County, CO, 218 groundwater samples were analyzed for BTEX following 77

477 industry reported spills of oil or produced waters. Following remediation at several sites,

478 benzene remained above the maximum contaminant limit for groundwater in $59 \%$ of sites, and

479 above these levels outside of the remediation area in 37\% of sites (Gross et al., 2013). In Garfield

480 County, CO, groundwater samples were collected in a high density shale gas drilling region and

481 analyzed for the endocrine disruption capacity (EDC) of the solid phase extracts of these fluids

482 (Kassotis et al., 2014). In 39 samples, 89\% of samples exhibited estrogenic activity, 41\% anti-

483 estrogenic, $12 \%$ androgenic, and $46 \%$ anti-androgenic activity; significantly higher than nearby

484 drilling sparse control sites. These high EDC activities were suspected to be related to

485 groundwater contamination due to HVHF activities from any of the more than 100 known EDCs

486 found in HVHF additives (Kassotis et al., 2014).

487 Following complaints of residents, the EPA investigated groundwater contamination in

488 Pavilion, WY suspected to be associated with the HVHF of shallow gas wells through the

489 installation of several shallow and deep groundwater monitoring wells (DiGiulio and Jackson,

490 2016a; DiGiulio et al., 2011). Multiple phases of monitoring were performed beginning with

491 existing residential and municipal wells, followed by shallow monitoring wells, and finally by

492 two explicitly drilled deep monitoring wells (235 m, $295 \mathrm{~m})$ (DiGiulio et al., 2011). Shallow

493 wells had high levels of BTEX, diesel and gas related compounds, and other hydrocarbons, but

494 ultimately were suspected of contamination by the use of surface unlined pits where fluids

495 including diesel used for gas extraction were stored (DiGiulio and Jackson, 2016a). However,

496 organic compounds identified in deep groundwater monitoring wells were different than those 
497 identified in surface wells and a number of known synthetic organic compounds used for HVHF

498 were identified (DiGiulio and Jackson, 2016a; DiGiulio et al., 2011). These included isopropanol

499 (biocide, surfactant, breakers, foaming agents), nonylphenol and octylphenol (surfactants),

500 diethylene glycol, triethylene glycol, tetraethylene glycol (solvent, foaming agent), 2-

501 butoxyethanol (gelling agent), and a suspected degradation product of possible undisclosed

502 additives, tert-butyl alcohol (DiGiulio and Jackson, 2016a; DiGiulio et al., 2011). Aromatic

503 solvent, diesel oil, heavy aromatic petroleum naphtha, toluene, xylene and petroleum raffinates

504 (material remaining following extraction of specific petroleum products) were reported as

505 fracturing fluid additives in the nearby well, and a number of compounds reflecting these

506 additives were identified in the monitoring wells including BTEX, trimethylbenzenes,

507 naphthalenes, and phenols (DiGiulio and Jackson, 2016a; DiGiulio et al., 2011). Diesel and gas

508 related organic compounds in 23 of 28 nearby domestic well samples correlated with reports of

509 foul odors (DiGiulio et al., 2011). Phthalates, acetone, 2-butanone, and 3-methyl-2-pentanone,

510 benzoic acid, and other small organic acids were also identified in the groundwater samples.

511 In the EPA retrospective case studies (Retrospective Case Study in Killdeer, North

512 Dakota: Study of the Potential Impacts of Hydraulic Fracturing on Drinking Water Resources,

513 2015, Retrospective Case Study in Northeastern Pennsylvania: Study of the Potential Impacts of

514 Hydraulic Fracturing on Drinking Water Resources, 2015, Retrospective Case Study in

515 Southwestern Pennsylvania Study of the Potential Impacts of Hydraulic Fracturing on Drinking

516 Water Resources, 2015, Retrospective Case Study in the Raton Basin, Colorado: Study of the

517 Potential Impacts of Hydraulic Fracturing on Drinking Water Resources, 2015, Retrospective

518 Case Study in Wise County, Texas: Study of the Potential Impacts of Hydraulic Fracturing on

519 Drinking Water Resources, 2015), a suite of organic compounds including VOCs, SVOCs, and 
520 DRO and GRO compounds were analyzed in groundwater and surface water samples based on

521 complaints of changes in water quality. In the Northeastern PA and Southwestern PA case

522 studies (Marcellus shale), low level and sporadic detections of organic compounds including

523 phthalates, toluene, benzene, 1,2,3-trimethylbenzene, 1,2,4-trimethylbenzene, chloroform,

524 acetone, phenol, 2-butoxyethanol, and phthalates as well as DRO and GRO were suspected

525 laboratory and field contaminants and inconsistent with contamination due to hydraulic

526 fracturing activities due to a lack of other potential indicators such as chloride, TDS, Ba, or $\mathrm{Sr}$

527 (Retrospective Case Study in Northeastern Pennsylvania: Study of the Potential Impacts of

528 Hydraulic Fracturing on Drinking Water Resources, 2015, Retrospective Case Study in

529 Southwestern Pennsylvania Study of the Potential Impacts of Hydraulic Fracturing on Drinking

530 Water Resources, 2015). Similarly, detections of these compounds as well as xylene in the

531 Killdeer aquifer were presumed to be laboratory contaminants with the exception of tert-butyl

532 alcohol (TBA) at two groundwater sites. At these sites, along the groundwater flowpath from a

533 documented well blowout, TBA was elevated $\left(975 \mu \mathrm{g} \mathrm{L}^{-1}\right)$ and had a documented HVHF fluid

534 source. TBA as well as chloride decreased over the four time points, consistent with the

535 movement of a contaminant plume through the wells (U.S. EPA, 2015b). Acetate and formate,

536 indicators of hydrocarbon degradation, were detected in $31 \%$ of wells and $10 \%$ of wells,

537 respectively, in the sampled groundwaters (U.S. EPA, 2015b). In Wise County, TX (Barnett

538 Shale), VOCs were detected, including tert-butyl alcohol, methyl tert-butyl ether, ethyl tert-butyl

539 ether, tert-amyl methyl ether, $\mathrm{m}+\mathrm{p}$-xylene, o-xylene, 1,2,4-trimethylbenzene, and benzene;

540 however, the sources of the compounds was considered unidentified because there were not

541 repeated detections and no glycol ethers indicative of hydraulic fracturing (U.S. EPA, 2015e). In

542 the Raton Basin, CO, (coal bed methane) a large number of organic chemicals were detected, 
543 representing possible HVHF fluid additives, as well potential natural sources (U.S. EPA, 2015c).

544 VOCs such as BTEX detected in this study were interpreted to originate from water-rock

545 interactions or enhanced solubilization due to the solvent-like properties of the injection fluid

546 (U.S. EPA, 2015c). Again, TBA was detected in some sites at high levels (maximum 1,310 $\mu \mathrm{g} \mathrm{L}^{-}$

$544^{1}$ ), but the observation was interpreted as not necessarily representing contamination from a

548 HVHF fluid event because neither TBA or its parent compounds were disclosed, and sufficient

549 spatial data or adequate pre-HVHF controls did not exist (U.S. EPA, 2015c).

550 These studies and their critics bring up common issues in interpreting environmental data

551 and associating the observations with a specific contamination source. First, in nearly all

552 scenarios, relatively few baseline data exists for sampling locations as all extensive studies have

553 been completed in response to perceived threats or changes. Baseline data for organic

554 compounds are rarer than for inorganic ions and are completely absent for specific tracers that

555 may be strong indicators of a HVHF source. Reference sites in the same geologic region are

556 sometimes used as a control variable, but these are also susceptible to contamination from past

557 events, especially considering shale gas regions are co-located in conventional oil and gas

558 regions that have been drilled for longer time periods. Unfortunately, baseline data cannot

559 retroactively be collected and this will continue to be a critical issue in interpreting data. A

560 second common critique is of the observations of some compounds associated with HVHF, but

561 an absence of others associated with HVHF (Connor et al., 2016; McHugh et al., 2016, 2014).

562 Fontenot, Meik and colleagues responded in describing the role changing $\mathrm{pH}$ and redox

563 conditions plays on dissolved metal concentrations (Fontenot et al., 2014; Meik et al., 2016).

564 DiGiulio and Jackson responded by explaining that heterogeneity in itself is indicative of

565 anthropogenic impact if groundwater samples are obtained from the same formation (DiGiulio 
566 and Jackson, 2016b). Previous research has shown the differences in groundwater transport of

567 contaminants based on the strength of their interaction with the geologic formation and soils, as

568 reactive or nonreactive solutes (Brusseau, 1994; Burr et al., 1994; Mackay et al., 1986).

569 Nonreactive solutes such as chloride will be transported faster than reactive organic compounds

570 associated with HVHF fluids which may be retarded through interactions with the geologic

571 formations and organic carbon present in these formations (Allen-King et al., 2002; Mackay et 572 al., 1986).

\subsection{Simulated bioreactor "spills"}

Two published studies have simulated spills of HVHF fluids at the bench scale under

576 aerobic conditions. In each of these studies, a synthetic mixture of HVHF fluid additives was

577 mixed with natural microbial communities and the organic additives quantified over 7-180 days.

578 In an aerobic solution inoculated with an activated sludge microbial community, the overall

579 dissolved organic carbon (DOC) content decreased by $52 \%$ in 6.5 days in freshwater and a $20 \mathrm{~g}$

$580 \mathrm{~L}^{-1}$ saline solution. At higher salinities $\left(40 \mathrm{~g} \mathrm{~L}^{-1}\right.$ and $\left.60 \mathrm{~g} \mathrm{~L}^{-1}\right)$, DOC did not change significantly

581 over the same time period. Acetone, a degradation product, increased by two orders of

582 magnitude, and volatile additives such as naphthalene and benzene were rapidly decreased in

583 concentration, likely due to volatilization (Kekacs et al., 2015). In the second study, varying

584 combinations of fracturing fluid additives were mixed with agricultural soil and the in situ

585 microbial community and their changes tracked to understand co-contaminant interactions over

586180 days (McLaughlin et al., 2016). The presence of glutaraldehyde biocide impeded the

587 degradation of polyethylene glycol surfactants, and high salt levels also severely inhibited their 
588 degradation. Polyacrylamide was not degraded over the duration of the experiment, but did react

589 with the biocide glutaraldehyde (McLaughlin et al., 2016).

\section{Flowback and Produced Water Treatment}

High total dissolved solids (TDS) create a significant challenge for the treatment of

593 flowback and produced waters (Gregory et al., 2011; Kondash et al., 2017), hence wastewaters

594 are frequently sent to Class II disposal wells (U.S. EPA, 2016). TDS varies by basin and

595 increases over the lifetime of the well (Kondash et al., 2017); high levels of TDS limit direct

596 reuse due to scaling problems and reduced effectiveness of friction reducers (Gregory et al.,

597 2011; Kamel and Shah, 2009). The fate of the treated effluent determines the type and amount of

598 treatment required. The treatment for reuse in HVHF requires a different level of treatment (e.g.,

599 precipitation of scaling cations, disinfection, (Lester et al., 2015)) than other beneficial reuses or

600 discharge to the environment (Estrada and Bhamidimarri, 2016; Gregory et al., 2011). High TDS

601 formation produced waters, such as the Bakken or Marcellus, cannot be directly reused and TDS

602 must be first reduced either by using dilution or treatment, which is in contrast to formations

603 such as the Niobrara or Eagle Ford, that have much lower TDS (Kondash et al., 2017).

604 The wide variety of treatment methods used for flowback and produced waters have been

605 reviewed previously (Drewes et al., 2009; Estrada and Bhamidimarri, 2016; Fakhru'l-Razi et al.,

606 2009; Gregory et al., 2011; U.S. EPA, 2016). Traditional oil and gas centralized waste treatment

607 and municipal treatment facilities (no longer in use) have not been shown to sufficiently remove

608 key contaminants from HVHF wastewaters prior to discharging to streams (Ferrar et al., 2013;

609 Getzinger et al., 2015; Warner et al., 2013). Thermal distillation and crystallization technologies

610 efficiently remove TDS but may be energy intensive, while membrane technologies such as 
611 reverse osmosis, forward osmosis, and nanofiltration are prone to clogging and fouling and are

612 more effective when combined with pre-treatment technologies (Coday et al., 2014; Estrada and

613 Bhamidimarri, 2016; Gregory et al., 2011; Jang et al., 2017; Riley et al., 2016; Shaffer et al., 614 2013).

615 Few individual organic compounds have been tracked through industrial treatment

616 facilities, although any given treatment train could neglect a number of organic compounds,

617 additives, and transformation products. The effectiveness of a given treatment method on organic

618 compounds is frequently reported only for regulated hydrocarbons such as total oil and grease

619 (Drewes et al., 2009), or other bulk measurements including dissolved organic carbon (DOC),

620 chemical oxygen demand and 3D excitation-emission matrix fluorescence (e.g., Hickenbottom et

621 al., 2013; Lobo et al., 2016; Riley et al., 2016).

622 Bench-scale experiments have examined the removal efficiencies of a number of organic

623 compounds frequently found in HVHF wastewaters. Guar gum, a common HVHF additive likely

624 to foul membranes, was effectively removed biologically ( $90 \%)$ at low TDS using an activated

625 sludge mixture (Lester et al., 2014). In a different synthetic HVHF wastewater, forward osmosis

626 rejected $>99.9 \%$ of oil while acetic acid rejection was much lower at only $82 \%\left(23{ }^{\circ} \mathrm{C}\right)$ and $74 \%$

$627\left(60^{\circ} \mathrm{C}\right)($ Zhang et al., 2014). More hydrophobic compounds, including alkanes and polycyclic

628 aromatic hydrocarbons, were removed with 90-99\% efficiency using forward osmosis (Bell et

629 al., 2017). Powdered activated carbon (PAC) combined with coagulants were tested for removal

630 efficiency of total petroleum hydrocarbons and polyethylene glycols from actual HVHF

631 flowback and produced waters. PAC was shown to be effective at high doses $\left(750 \mathrm{mg} \mathrm{L}^{-1}, 1,000\right.$

$632 \mathrm{mg} \mathrm{L}^{-1}$ PAC) for polyethylene glycol removal in all cases and in three out of four wastewaters

633 for total petroleum hydrocarbons (Rosenblum et al., 2016). However, these specific classes 
634 represented only a fraction of the DOC, and much of the DOC was not removed (52-90\%) using

635 PAC (Rosenblum et al., 2016).

636

\section{Considerations and Future Research}

Reviewing and synthesizing the literature on HVHF organic compounds remains

639 challenging due to inconsistencies in reporting information such as age of fluids and sampling

640 techniques (storage conditions, head-space free, etc.). Building on the suggested reporting

641 parameters listed by Bibby and colleagues (2013): (1) shale play/formation (2)

642 fracturing/stimulation approach (3) well age (4) water quality (bulk parameters, inorganics), we

643 suggest reporting additional information helpful in interpreting organic analyses: (5) Sample

644 location (well, separator, collection tank) (6) Sampling information (bottle type, head-space free, 645 storage conditions and duration).

646 Gas chromatography paired with mass spectrometry has been the most frequently used

647 technique for organic compound analysis of HVHF fluids and wastewaters. GC and GC-MS

648 have a large number of standardized methods for VOCs and SVOCs including oil and gas

649 compounds in HVHF fluids. Continued research on these compounds is critical in understanding

650 basin to basin variability, differences in HVHF techniques, and quantifying many known toxic

651 compounds (Elliott et al., 2017). Quantification using standard methods is essential for tracking

652 the distribution of HVHF fluids and wastewaters when they accidentally enter the environment.

653 The Marcellus shale region is the dominant location of HVHF fluid samples analyzed for

654 organic compounds, followed by the Denver-Julesberg basin. Although the Marcellus is the

655 dominant shale gas producer, oil is not co-produced in this formation (Drilling Productivity

656 Report, 2017), indicating a lower complexity background organic carbon pool compared to a 
657 shale oil (Bae et al., 2010). Analysis of the Denver-Julesberg, Permian, and other co-producing

658 gas and oil basins will inevitably differ in their distribution of geogenic organic compounds

659 compared to gas-only basins. Future research should work to diversify basin coverage across gas,

660 oil, and co-producing basins to understand the variability in geogenic signatures and diversity of

661 HVHF fluid systems. Treatment goals and techniques also vary by basin and further

662 investigation into the removal rates of specific organic compounds of interest is needed across

663 treatment schemes developed across all basins (i.e., halogenated organic compounds, BTEX,

664 known toxic additives).

665 DOC concentrations compared to concentrations of specific organic compounds show

666 that a large portion of the organic carbon pool remains uncharacterized. Additional research

667 needs to build on recent progress developing new analytical methods that can overcome the

668 extremely complex high salinity matrix for known additives and identified transformation

669 products in these fluids, particularly using LC-MS techniques. Continued research using

670 alternative extraction methods and high-resolution non-targeted techniques will allow for the

671 identification of the diverse transformation products in HVHF fluids and wastewaters during

672 treatment as well as environmental contamination events. New standards must be made available

673 for known additives, geogenic organic compounds, and newly identified transformation products

674 to further progress in this field and gain a broad understanding of the fate of organic compounds

675 in HVHF.

676

$677 \quad 7.0$ Conclusions

678 Organic compounds are used as HVHF fluid additives and a number of these have been

679 detected in these flowback and produced waters. Geogenic compounds and transformation 
680 products from biotic and abiotic processes have also been identified in these wastewaters. BTEX,

681 acetate, and acetone are the most frequently analyzed and detected organic compounds, and

682 VOC and SVOCs are commonly analyzed. However, non-targeted techniques have highlighted

683 the diversity of organic compounds that may be present in a given fluid for which new standards

684 and analytical methods need to be developed. Organic chemical additives have been used in

685 combination with inorganic chemical tracers to infer and track environmental contamination

686 events. Further analytical development will benefit these investigations, allowing quantitative

687 comparisons of new organic chemical tracers highly specific to HVHF to be made against

688 background levels.

689

690

691 Acknowledgements

692 Financial assistance was obtained from NSF CBET Award \#1604475/1604432 to

693 Michael Gonsior and Paula Mouser. This is contribution (xxxx, to be filled in after acceptance of

694 manuscript) of the University of Maryland Center for Environmental Science, Chesapeake

695 Biological Laboratory. 


\section{References}

Abualfaraj, N., Gurian, P.L., Olson, M.S., 2014. Characterization of Marcellus Shale Flowback Water. Environ. Eng. Sci. 140716083132007. doi:10.1089/ees.2014.0001

Akob, D.M., Cozzarelli, I.M., Dunlap, D.S., Rowan, E.L., Lorah, M.M., 2015. Organic and inorganic composition and microbiology of produced waters from Pennsylvania shale gas wells. Appl. Geochem. 60, 116-125. doi:10.1016/j.apgeochem.2015.04.011

Akob, D.M., Mumford, A.C., Orem, W., Engle, M.A., Klinges, J.G., Kent, D.B., Cozzarelli, I.M., 2016. Wastewater Disposal from Unconventional Oil and Gas Development Degrades Stream Quality at a West Virginia Injection Facility. Environ. Sci. Technol. 50, 5517-5525. doi:10.1021/acs.est.6b00428

Allen-King, R.. ., Grathwohl, P., Ball, W.P., 2002. New modeling paradigms for the sorption of hydrophobic organic chemicals to heterogeneous carbonaceous matter in soils, sediments, and rocks. Adv. Water Resour. 25, 985-1016.

Bae, E., Na, J.-G., Chung, S.H., Kim, H.S., Kim, S., 2010. Identification of about 30000 Chemical Components in Shale Oils by Electrospray Ionization (ESI) and Atmospheric Pressure Photoionization (APPI) Coupled with 15 T Fourier Transform Ion Cyclotron Resonance Mass Spectrometry (FT-ICR MS) and a Comparison to Conventional Oil. Energy Fuels 24, 2563-2569. doi:10.1021/ef100060b

Bell, E.A., Poynor, T.E., Newhart, K.B., Regnery, J., Coday, B.D., Cath, T.Y., 2017. Produced water treatment using forward osmosis membranes: Evaluation of extended-time performance and fouling. J. Membr. Sci. 525, 77-88. doi:10.1016/j.memsci.2016.10.032

Bibby, K.J., Brantley, S.L., Reible, D.D., Linden, K.G., Mouser, P.J., Gregory, K.B., Ellis, B.R., Vidic, R.D., 2013. Suggested Reporting Parameters for Investigations of Wastewater from Unconventional Shale Gas Extraction. Environ. Sci. Technol. 47, 13220-13221. doi: $10.1021 / \mathrm{es} 404960 \mathrm{z}$

Brusseau, M.L., 1994. Transport of reactive contaminants in heterogeneous porous media. Rev. Geophys. 32, 285-313.

Burr, D.A., Sudicky, E.A., Naff, R.L., 1994. Nonreactive and reactive solute transport in threedimensional heterogeneous porous media: Mean displacement, plume spreading, and uncertainty. Water Resour. Res. 30, 791-815.

Callbeck, C.M., Agrawal, A., Voordouw, G., 2013. Acetate Production from Oil under SulfateReducing Conditions in Bioreactors Injected with Sulfate and Nitrate. Appl. Environ. Microbiol. 79, 5059-5068. doi:10.1128/AEM.01251-13

Chapman, E.C., Capo, R.C., Stewart, B.W., Kirby, C.S., Hammack, R.W., Schroeder, K.T., Edenborn, H.M., 2012. Geochemical and Strontium Isotope Characterization of Produced Waters from Marcellus Shale Natural Gas Extraction. Environ. Sci. Technol. 46, 35453553. doi:10.1021/es204005g

Cluff, M.A., Hartsock, A., MacRae, J.D., Carter, K., Mouser, P.J., 2014. Temporal Changes in Microbial Ecology and Geochemistry in Produced Water from Hydraulically Fractured Marcellus Shale Gas Wells. Environ. Sci. Technol. 48, 6508-6517. doi:10.1021/es501173p

Coday, B.D., Xu, P., Beaudry, E.G., Herron, J., Lampi, K., Hancock, N.T., Cath, T.Y., 2014. The sweet spot of forward osmosis: Treatment of produced water, drilling wastewater, and other complex and difficult liquid streams. Desalination 333, 23-35. doi:10.1016/j.desal.2013.11.014 
Connor, J.A., Walker, K., Molofsky, L., Baca, E., Gie, E., McHugh, T., 2016. Comment on "Impact to Underground Sources of Drinking Water and Domestic Wells from Production Well Stimulation and Completion Practices in the Pavillion, Wyoming, Field." Environ. Sci. Technol. 50, 10769-10770.

Cozzarelli, I.M., Skalak, K.J., Kent, D.B., Engle, M.A., Benthem, A., Mumford, A.C., Haase, K., Farag, A., Harper, D., Nagel, S.C., Iwanowicz, L.R., Orem, W.H., Akob, D.M., Jaeschke, J.B., Galloway, J., Kohler, M., Stoliker, D.L., Jolly, G.D., 2017. Environmental signatures and effects of an oil and gas wastewater spill in the Williston Basin, North Dakota. Sci. Total Environ. 579, 1781-1793. doi:10.1016/j.scitotenv.2016.11.157

DiGiulio, D.C., Jackson, R.B., 2016a. Impact to Underground Sources of Drinking Water and Domestic Wells from Production Well Stimulation and Completion Practices in the Pavillion, Wyoming, Field. Environ. Sci. Technol. 50, 4524-4536. doi:10.1021/acs.est.5b04970

DiGiulio, D.C., Jackson, R.B., 2016b. Response to Comment on "Impact to Underground Sources of Drinking Water and Domestic Wells from Production Well Stimulation and Completion Practices in the Pavillion, Wyoming Field.” Environ. Sci. Technol. 50, 10771-10772. doi:10.1021/acs.est.6b04300

Dominic C. DiGiulio, Richard T. Wilkin, Carlyle Miller, Gregory Oberley, 2011. Investigation of Ground Water Contamination near Pavilion, Wyoming (Draft No. EPA 600/R00/000). US Environmental Protection Agency.

Drewes, J., T. Cath, J. Debroux, J. Veil, 2009. An Integrated Framework for Treatment and Management of Produced Water: Technical Assessment of Produced Water Treatment Technologies (No. RPSEA Project 07122-12.).

Drilling Productivity Report For key tight oil and shale regions, 2017. . U.S. Energy Information Administration.

Drollette, B.D., Hoelzer, K., Warner, N.R., Darrah, T.H., Karatum, O., O’Connor, M.P., Nelson, R.K., Fernandez, L.A., Reddy, C.M., Vengosh, A., Jackson, R.B., Elsner, M., Plata, D.L., 2015. Elevated levels of diesel range organic compounds in groundwater near Marcellus gas operations are derived from surface activities. Proc. Natl. Acad. Sci. 112, 1318413189. doi:10.1073/pnas.1511474112

Elliott, E.G., Ettinger, A.S., Leaderer, B.P., Bracken, M.B., Deziel, N.C., 2017. A systematic evaluation of chemicals in hydraulic-fracturing fluids and wastewater for reproductive and developmental toxicity. J. Expo. Sci. Environ. Epidemiol. 27, 90-99.

Elsner, M., Hoelzer, K., 2016. Quantitative Survey and Structural Classification of Hydraulic Fracturing Chemicals Reported in Unconventional Gas Production. Environ. Sci. Technol. 50, 3290-3314. doi:10.1021/acs.est.5b02818

Engle, M.A., Rowan, E.L., 2014. Geochemical evolution of produced waters from hydraulic fracturing of the Marcellus Shale, northern Appalachian Basin: A multivariate compositional data analysis approach. Int. J. Coal Geol. 126, 45-56. doi:10.1016/j.coal.2013.11.010

Estrada, J.M., Bhamidimarri, R., 2016. A review of the issues and treatment options for wastewater from shale gas extraction by hydraulic fracturing. Fuel 182, 292-303. doi:10.1016/j.fuel.2016.05.051

Fakhru'l-Razi, A., Pendashteh, A., Abdullah, L.C., Biak, D.R.A., Madaeni, S.S., Abidin, Z.Z., 2009. Review of technologies for oil and gas produced water treatment. J. Hazard. Mater. 170, 530-551. doi:10.1016/j.jhazmat.2009.05.044 
Ferrar, K.J., Michanowicz, D.R., Christen, C.L., Mulcahy, N., Malone, S.L., Sharma, R.K., 2013. Assessment of Effluent Contaminants from Three Facilities Discharging Marcellus Shale Wastewater to Surface Waters in Pennsylvania. Environ. Sci. Technol. 130314103725000. doi:10.1021/es301411q

Ferrer, I., Thurman, E.M., 2015a. Chemical constituents and analytical approaches for hydraulic fracturing waters. Trends Environ. Anal. Chem. 5, 18-25. doi:10.1016/j.teac.2015.01.003

Ferrer, I., Thurman, E.M., 2015b. Analysis of hydraulic fracturing additives by LC/Q-TOF-MS. Anal. Bioanal. Chem. 407, 6417-6428. doi:10.1007/s00216-015-8780-5

Fontenot, B.E., Hunt, L.R., Hildenbrand, Z.L., Carlton Jr., D.D., Oka, H., Walton, J.L., Hopkins, D., Osorio, A., Bjorndal, B., Hu, Q.H., Schug, K.A., 2013. An Evaluation of Water Quality in Private Drinking Water Wells Near Natural Gas Extraction Sites in the Barnett Shale Formation. Environ. Sci. Technol. 47, 10032-10040. doi:10.1021/es4011724

FracFocus, website: fracfocus.org, n.d.

Getzinger, G.J., O’Connor, M.P., Hoelzer, K., Drollette, B.D., Karatum, O., Deshusses, M.A., Ferguson, P.L., Elsner, M., Plata, D.L., 2015. Natural Gas Residual Fluids: Sources, Endpoints, and Organic Chemical Composition after Centralized Waste Treatment in Pennsylvania. Environ. Sci. Technol. 49, 8347-8355. doi:10.1021/acs.est.5b00471

Gregory, K.B., Vidic, R.D., Dzombak, D.A., 2011. Water Management Challenges Associated with the Production of Shale Gas by Hydraulic Fracturing. Elements 7, 181-186. doi:10.2113/gselements.7.3.181

Gross, S.A., Avens, H.J., Banducci, A.M., Sahmel, J., Panko, J.M., Tvermoes, B.E., 2013. Analysis of BTEX groundwater concentrations from surface spills associated with hydraulic fracturing operations. J. Air Waste Manag. Assoc. 63, 424-432. doi:10.1080/10962247.2012.759166

Hayes, T., 2009. Sampling and Analysis of Water Streams Associated with the Development of Marcellus Shale Gas (Final Report). Gas Technology Institute.

Hickenbottom, K.L., Hancock, N.T., Hutchings, N.R., Appleton, E.W., Beaudry, E.G., Xu, P., Cath, T.Y., 2013. Forward osmosis treatment of drilling mud and fracturing wastewater from oil and gas operations. Desalination 312, 60-66. doi:10.1016/j.desal.2012.05.037

Hildenbrand, Z.L., Carlton, D.D., Fontenot, B.E., Meik, J.M., Walton, J.L., Taylor, J.T., Thacker, J.B., Korlie, S., Shelor, C.P., Henderson, D., Kadjo, A.F., Roelke, C.E., Hudak, P.F., Burton, T., Rifai, H.S., Schug, K.A., 2015. A Comprehensive Analysis of Groundwater Quality in The Barnett Shale Region. Environ. Sci. Technol. 49, 82548262. doi:10.1021/acs.est.5b01526

Hildenbrand, Z.L., Carlton, D.D., Fontenot, B.E., Meik, J.M., Walton, J.L., Thacker, J.B., Korlie, S., Shelor, C.P., Kadjo, A.F., Clark, A., Usenko, S., Hamilton, J.S., Mach, P.M., Verbeck, G.F., Hudak, P., Schug, K.A., 2016. Temporal variation in groundwater quality in the Permian Basin of Texas, a region of increasing unconventional oil and gas development. Sci. Total Environ. 562, 906-913. doi:10.1016/j.scitotenv.2016.04.144

Hoelzer, K., Sumner, A.J., Karatum, O., Nelson, R.K., Drollette, B.D., O'Connor, M.P., D’Ambro, E.L., Getzinger, G.J., Ferguson, P.L., Reddy, C.M., Elsner, M., Plata, D.L., 2016. Indications of Transformation Products from Hydraulic Fracturing Additives in Shale-Gas Wastewater. Environ. Sci. Technol. 50, 8036-8048. doi:10.1021/acs.est.6b00430 
831

832

833

834

835

836

837

838

839

840

841

842

843

844

845

846

847

848

849

850

851

852

853

854

855

856

857

858

859

860

861

862

863

864

865

866

867

868

869

870

871

872

873

874

875

Jang, E., Jeong, S., Chung, E., 2017. Application of three different water treatment technologies to shale gas produced water. Geosystem Eng. 20, 104-110. doi:10.1080/12269328.2016.1239553

Kahrilas, G.A., Blotevogel, J., Corrin, E.R., Borch, T., 2016. Downhole Transformation of the Hydraulic Fracturing Fluid Biocide Glutaraldehyde: Implications for Flowback and Produced Water Quality. Environ. Sci. Technol. 50, 11414-11423. doi:10.1021/acs.est.6b02881

Kahrilas, G.A., Blotevogel, J., Stewart, P.S., Borch, T., 2015. Biocides in Hydraulic Fracturing Fluids: A Critical Review of Their Usage, Mobility, Degradation, and Toxicity. Environ. Sci. Technol. 49, 16-32. doi:10.1021/es503724k

Kamel, A., Shah, S.N., 2009. Effects of salinity and temperature on drag reduction characteristics of polymers in straight circular pipes. J. Pet. Sci. Eng. 67, 23-33. doi:10.1016/j.petrol.2009.02.004

Kassotis, C.D., Tillitt, D.E., Davis, J.W., Hormann, A.M., Nagel, S.C., 2014. Estrogen and Androgen Receptor Activities of Hydraulic Fracturing Chemicals and Surface and Ground Water in a Drilling-Dense Region. Endocrinology 155, 897-907. doi:10.1210/en.2013-1697

Kekacs, D., Drollette, B.D., Brooker, M., Plata, D.L., Mouser, P.J., 2015. Aerobic biodegradation of organic compounds in hydraulic fracturing fluids. Biodegradation. doi:10.1007/s10532-015-9733-6

Khan, N.A., Engle, M., Dungan, B., Holguin, F.O., Xu, P., Carroll, K.C., 2016. Volatile-organic molecular characterization of shale-oil produced water from the Permian Basin. Chemosphere 148, 126-136. doi:10.1016/j.chemosphere.2015.12.116

Kondash, A., Vengosh, A., 2015. Water Footprint of Hydraulic Fracturing. Environ. Sci. Technol. Lett. 150918090943001. doi:10.1021/acs.estlett.5b00211

Kondash, A.J., Albright, E., Vengosh, A., 2017. Quantity of flowback and produced waters from unconventional oil and gas exploration. Sci. Total Environ. 574, 314-321. doi:10.1016/j.scitotenv.2016.09.069

Lester, Y., Ferrer, I., Thurman, E.M., Sitterley, K.A., Korak, J.A., Aiken, G., Linden, K.G., 2015. Characterization of hydraulic fracturing flowback water in Colorado: Implications for water treatment. Sci. Total Environ. 512-513, 637-644. doi:10.1016/j.scitotenv.2015.01.043

Lester, Y., Sharpless, C.M., Mamane, H., Linden, K.G., 2013. Production of Photo-oxidants by Dissolved Organic Matter During UV Water Treatment. Environ. Sci. Technol. 47, 11726-11733. doi:10.1021/es402879x

Lester, Y., Yacob, T., Morrissey, I., Linden, K.G., 2014. Can We Treat Hydraulic Fracturing Flowback with a Conventional Biological Process? The Case of Guar Gum. Environ. Sci. Technol. Lett. 1, 133-136. doi:10.1021/ez4000115

Llewellyn, G.T., Dorman, F., Westland, J.L., Yoxtheimer, D., Grieve, P., Sowers, T., HumstonFulmer, E., Brantley, S.L., 2015. Evaluating a groundwater supply contamination incident attributed to Marcellus Shale gas development. Proc. Natl. Acad. Sci. 112, 63266330. doi:10.1073/pnas.1420279112

Lobo, F.L., Wang, H., Huggins, T., Rosenblum, J., Linden, K.G., Ren, Z.J., 2016. Low-energy hydraulic fracturing wastewater treatment via AC powered electrocoagulation with biochar. J. Hazard. Mater. 309, 180-184. doi:10.1016/j.jhazmat.2016.02.020 
876

877

878

879

880

881

882

883

884

885

886

887

888

889

890

891

892

893

894

895

896

897

898

899

900

901

902

903

904

905

906

907

908

909

910

911

912

913

914

915

916

917

918

919

920

921
Luek, J.L., Schmitt-Kopplin, P., Mouser, P.J., Petty, W.T., Richardson, S.D., Gonsior, M., 2017. Halogenated organic compounds identified in hydraulic fracturing wastewaters using ultrahigh resolution mass spectrometry. Environ. Sci. Technol. doi:10.1021/acs.est.6b06213

Mackay, D.M., Freyberg, D.L., Roberts, P.V., Cherry, J.A., 1986. A Natural Gradient Experiment on Solute Transport in a Sand Aquifer 1. Approach and Overview of Plume Movement. Water Resour. Res. 22, 2017-2029.

Maguire-Boyle, S.J., Barron, A.R., 2014. Organic compounds in produced waters from shale gas wells. Env. Sci Process. Impacts 16, 2237-2248. doi:10.1039/C4EM00376D

Maillard, J.-Y., 2002. Bacterial target sites for biocide action. J. Appl. Microbiol. 92.

Marshall, A.G., Hendrickson, C.L., 2008. High-Resolution Mass Spectrometers. Annu. Rev. Anal. Chem. 1, 579-599. doi:10.1146/annurev.anchem.1.031207.112945

McHugh, T., Molofsky, L., Daus, A., Connor, J., 2014. Comment on “An Evaluation of Water Quality in Private Drinking Water Wells Near Natural Gas Extraction Sites in the Barnett Shale Formation." Environ. Sci. Technol. 48, 3595-3596. doi:10.1021/es405772d

McHugh, T., Molofsky, L., Fitzgerald, L., Connor, J., 2016. Comment on "A Comprehensive Analysis of Groundwater Quality in The Barnett Shale Region.” Environ. Sci. Technol. 50, 496-497. doi:10.1021/acs.est.5b05067

McLaughlin, M.C., Borch, T., Blotevogel, J., 2016. Spills of Hydraulic Fracturing Chemicals on Agricultural Topsoil: Biodegradation, Sorption, and Co-contaminant Interactions. Environ. Sci. Technol. doi:10.1021/acs.est.6b00240

Mohan, A.M., Bibby, K.J., Lipus, D., Hammack, R.W., Gregory, K.B., 2014. The Functional Potential of Microbial Communities in Hydraulic Fracturing Source Water and Produced Water from Natural Gas Extraction Characterized by Metagenomic Sequencing. PLoS ONE 9, e107682. doi:10.1371/journal.pone.0107682

Müller, V., 2008. Bacterial fermentation. eLS.

Murali Mohan, A., Hartsock, A., Bibby, K.J., Hammack, R.W., Vidic, R.D., Gregory, K.B., 2013a. Microbial Community Changes in Hydraulic Fracturing Fluids and Produced Water from Shale Gas Extraction. Environ. Sci. Technol. 47, 13141-13150. doi:10.1021/es402928b

Murali Mohan, A., Hartsock, A., Hammack, R.W., Vidic, R.D., Gregory, K.B., 2013b. Microbial communities in flowback water impoundments from hydraulic fracturing for recovery of shale gas. FEMS Microbiol. Ecol. 86, 567-580. doi:10.1111/1574-6941.12183

Orem, W., Tatu, C., Varonka, M., Lerch, H., Bates, A., Engle, M., Crosby, L., McIntosh, J., 2014. Organic substances in produced and formation water from unconventional natural gas extraction in coal and shale. Int. J. Coal Geol. 126, 20-31.

doi:10.1016/j.coal.2014.01.003

Orem, W., Varonka, M., Crosby, L., Haase, K., Loftin, K., Hladik, M., Akob, D.M., Tatu, C., Mumford, A., Jaeschke, J., Bates, A., Schell, T., Cozzarelli, I., 2017. Organic geochemistry and toxicology of a stream impacted by unconventional oil and gas wastewater disposal operations. Appl. Geochem. 80, 155-167. doi:10.1016/j.apgeochem.2017.02.016

Orem, W.H., Voytek, M.A., Jones, E.J., Lerch, H.E., Bates, A.L., Corum, M.D., Warwick, P.D., Clark, A.C., 2010. Organic intermediates in the anaerobic biodegradation of coal to methane under laboratory conditions. Org. Geochem. 41, 997-1000.

doi:10.1016/j.orggeochem.2010.03.005 
922

923

924

925

926

927

928

929

930

931

932

933

934

935

936

937

938

939

940

941

942

943

944

945

946

947

948

949

950

951

952

953

954

955

956

957

958

959

960

961

962

963

964

965

966

967

Regnery, J., Coday, B.D., Riley, S.M., Cath, T.Y., 2016. Solid-phase extraction followed by gas chromatography-mass spectrometry for the quantitative analysis of semi-volatile hydrocarbons in hydraulic fracturing wastewaters. Anal Methods 8, 2058-2068. doi:10.1039/C6AY00169F

Riley, S.M., Oliveira, J.M.S., Regnery, J., Cath, T.Y., 2016. Hybrid membrane bio-systems for sustainable treatment of oil and gas produced water and fracturing flowback water. Sep. Purif. Technol. 171, 297-311. doi:10.1016/j.seppur.2016.07.008

Rogers, J.D., Burke, T.L., Osborn, S.G., Ryan, J.N., 2015. A framework for identifying organic compounds of concern in hydraulic fracturing fluids based on mobility and persistence in groundwater. Environ. Sci. Technol. Lett. 150515152302002. doi:10.1021/acs.estlett.5b00090

Rosenblum, J.S., Sitterley, K.A., Thurman, E.M., Ferrer, I., Linden, K.G., 2016. Hydraulic fracturing wastewater treatment by coagulation-adsorption for removal of organic compounds and turbidity. J. Environ. Chem. Eng. 4, 1978-1984. doi:10.1016/j.jece.2016.03.013

Rosenfeld, B., Simon, E., 1950. THE MECHANISM OF THE BUTANOL-ACETONE FERMENTATION I. THE RÔLE OF PYRUVATE AS AN INTERMEDIATE. J. Biol. Chem. 186, 395-404.

Schymanski, E.L., Jeon, J., Gulde, R., Fenner, K., Ruff, M., Singer, H.P., Hollender, J., 2014. Identifying Small Molecules via High Resolution Mass Spectrometry: Communicating Confidence. Environ. Sci. Technol. 140129110454000. doi:10.1021/es5002105

Shaffer, D.L., Arias Chavez, L.H., Ben-Sasson, M., Romero-Vargas Castrillón, S., Yip, N.Y., Elimelech, M., 2013. Desalination and Reuse of High-Salinity Shale Gas Produced Water: Drivers, Technologies, and Future Directions. Environ. Sci. Technol. 47, 95699583. doi:10.1021/es401966e

Stringfellow, W.T., Domen, J.K., Camarillo, M.K., Sandelin, W.L., Borglin, S., 2014. Physical, chemical, and biological characteristics of compounds used in hydraulic fracturing. J. Hazard. Mater. 275, 37-54. doi:10.1016/j.jhazmat.2014.04.040

Strong, L.C., Gould, T., Kasinkas, L., Sadowsky, M.J., Aksan, A., Wackett, L.P., 2013. Biodegradation in Waters from Hydraulic Fracturing: Chemistry, Microbiology, and Engineering. J. Environ. Eng. 140, B4013001.

Thacker, J., Carlton, D., Hildenbrand, Z., Kadjo, A., Schug, K., 2015. Chemical Analysis of Wastewater from Unconventional Drilling Operations. Water 7, 1568-1579. doi:10.3390/w7041568

Thurman, E.M., Ferrer, I., Blotevogel, J., Borch, T., 2014. Analysis of Hydraulic Fracturing Flowback and Produced Waters Using Accurate Mass: Identification of Ethoxylated Surfactants. Anal. Chem. 86, 9653-9661. doi:10.1021/ac502163k

U.S. EPA, 2016. Hydraulic Fracturing for Oil and Gas: Impacts from the Hydraulic Fracturing Water Cycle on Drinking Water Resources in the United States (Final Report). (No. EPA/600/R-16/236F). U.S. Environmental Protection Agency, Washington, DC.

U.S. EPA, 2015a. Retrospective Case Study in Northeastern Pennsylvania: Study of the Potential Impacts of Hydraulic Fracturing on Drinking Water Resources (No. EPA/600/R-14/088). US Environmental Protection Agency.

U.S. EPA, 2015b. Retrospective Case Study in Killdeer, North Dakota: Study of the Potential Impacts of Hydraulic Fracturing on Drinking Water Resources (No. EPA/600/R-14/103). US Environmental Protection Agency. 
U.S. EPA, 2015c. Retrospective Case Study in the Raton Basin, Colorado: Study of the Potential Impacts of Hydraulic Fracturing on Drinking Water Resources (No. EPA/600/R-14/091). US Environmental Protection Agency.

U.S. EPA, 2015d. Retrospective Case Study in Southwestern Pennsylvania Study of the Potential Impacts of Hydraulic Fracturing on Drinking Water Resources (No. EPA/600/R-14/084). US Environmental Protection Agency.

U.S. EPA, 2015e. Retrospective Case Study in Wise County, Texas: Study of the Potential Impacts of Hydraulic Fracturing on Drinking Water Resources (No. EPA/600/R-14/090). US Environmental Protection Agency.

Warner, N.R., Christie, C.A., Jackson, R.B., Vengosh, A., 2013. Impacts of Shale Gas Wastewater Disposal on Water Quality in Western Pennsylvania. Environ. Sci. Technol. 131002090059009. doi:10.1021/es402165b

Wolford, R., 2011. Characterization of organics in marcellus shale flowback and produced waters. Pennsylvania State University.

Zhang, S., Wang, P., Fu, X., Chung, T.-S., 2014. Sustainable water recovery from oily wastewater via forward osmosis-membrane distillation (FO-MD). Water Res. 52, 112 121. doi:10.1016/j.watres.2013.12.044

Ziemkiewicz, P., 2013. Characterization of liquid waste streams from shale gas development. AGH Drill. Oil Gas 30, 297. doi:10.7494/drill.2013.30.1.297

Ziemkiewicz, P.F., He, Y.T., 2015. Evolution of water chemistry during Marcellus Shale gas development: A case study in West Virginia. Chemosphere 134, 224-231.

doi:10.1016/j.chemosphere.2015.04.040 